\section{Zihin Yetersizliği Olan Öğrenciler İçin Okuma Müdahaleleri: Kültürel-Tarihsel Bir İnceleme}

\author{
Reading Interventions for Students with \\ Intellectual Disability: A Cultural- \\ Historical Review
}

Turkish Journal of Special Education

Research and Practice

2021, Volume 3 Number 1, p 47-71 https://dergipark.org.tr/trsped

DOI: 10.37233/TRSPED.2021.0112

Article History:

Received 8 March 2021

Revised 23 June 2021

Accepted 3 December 2021

Available online 15 December 2021

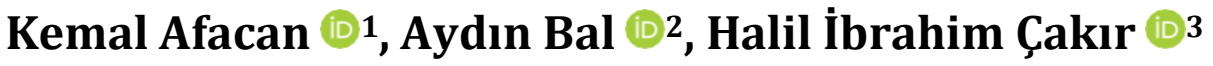

\begin{abstract}
Öz
$\mathrm{Bu}$ çalışmada zihin yetersizliği olan öğrencilere yönelik uygulanan okuma müdahalelerinin Lev Vygotsky'nin Kültürel-Tarihsel Etkinlik Kuramı bağlamında bir incelemesi sunulmuştur. Literatürde tespit edilen çalışmalar, özne, yöntem ve araç-gereçler, hedef, kurallar, ortam, iş bölümü ve sonuçlar açısından incelenmiştir. Çalışmada zihin yetersizliği olan öğrencilere yönelik uygulanan okuma müdahalelerinde öğretim sürecini etkileyen faktörlerin ortaya çıkarılması amaçlanmıştır. TR Dizin veri tabanı ve eğitim alanında Türkiye'de yayın yapan 24 derginin elektronik arşivleri incelenerek toplamda 11 makalenin derleme ölçütlerini karşıladığı tespit edilmiştir. Sonuçlar okuma müdahalelerinin araştırmacı temelli olduğunu, kullanılan araç-gereç ve yöntemler arasında farklılıklar bulunduğunu, öğrenci ve ailelerinin süreçte daha pasif hedef rolünde yer aldıklarını ve müdahale ortamlarının kaynaştırmayı desteklemediğini göstermiş̧ir. Sonuçlar genel literatür ve Kültürel-Tarihsel Etkinlik Kuramı bağlamında tartışllarak gelecek çalışmalar için önerilerde bulunulmuştur.
\end{abstract}

\section{Anahtar Sözcükler: Zihin yetersizliği, okuma, kültürel-tarihsel etkinlik kuramı, biçimlendirici müdahale.}

\begin{abstract}
In this study, an examination of the reading interventions applied to students with intellectual disabilities in the context of Lev Vygotsky's Cultural-Historical Activity Theory is presented. The studies identified in the literature were examined in terms of subject, artifacts, object, rules, community, division of labor and outcomes. In the study, it was aimed to reveal the factors affecting the teaching process in the reading interventions applied to students with intellectual disabilities. By examining the TR Index database and the electronic archives of 24 journals published in Turkey in the field of education, it was determined that a total of 11 articles met the inclusion criteria. The results showed that the reading interventions are researcher-based, there are differences in terms of the tools and methods used, the students and their families are more passive objects in the process, and the intervention environments do not support inclusion. The results were discussed in the context of the general literature and Cultural-Historical Activity Theory, and suggestions were made for future studies.
\end{abstract}

Keywords: Intellectual disability, reading, Cultural-Historical Activity Theory, formative intervention.

Önerilen Atıf Şekli (Suggested Citation): Afacan, K., Bal, A., \& Çakır, H.İ. (2021). Zihin yetersizliği olan öğrenciler için okuma müdahaleleri: Kültürel-tarihsel bir inceleme. Turkish Journal of Special Education Research and Practice, 3 (1), 47-71. https://doi.org/10.37233/TRSPED.2021.0112

\footnotetext{
${ }^{1}$ Artvin Çoruh Üniversitesi, Eğitim Fakültesi, Özel Eğitim Bölümü, Artvin, Türkiye, e-posta: kemalafacan@artvin.edu.tr, ORCID: https://orcid.org/0000-0002-2691-6397

2 University of Wisconsin-Madison, School of Education, Department of Rehabilitation Psychology and Special Education, WI, USA, e-posta: abal@wisc.edu, ORCID: $\underline{\text { https://orcid.org/0000-0001-7246-5876 }}$

${ }^{3}$ Giresun Üniversitesi, Eğitim Fakültesi, Özel Eğitim Bölümü, Giresun, Türkiye, e-posta: halil.cakir@giresun.edu.tr, ORCID:

https://orcid.org/0000-0001-5966-6489
} 


\section{Giriş}

Zihin yetersizliği olan öğrenciler zekâ testlerinde zihinsel işlevlerde ortalama zeka bölümünün iki standart sapma altında farklılık gösteren (örneğin 70 veya daha düşük zeka bölümü), sosyal ve pratik uyum becerilerinde yetersizlikleri ya da sinırlılıkları olan ve bu özellikleri 18 yaşından önceki gelişim döneminde ortaya çıkan öğrenciler olarak tanımlanmaktadır (American Association on Intellectual and Developmental Disabilities, 2010). Zihin yetersizliği olan öğrenciler homojen bir grup olmamakla birlikte, genel olarak zihin yetersizliği tanısı alan öğrencilerin öğrenme ile ilgili özellikleri incelendiğinde bu öğrencilerin diğer akranlarına kıyasla farklı performans sergiledikleri bulunmuştur. Örneğin, zihin yetersizliği olan öğrenciler zihin yetersizliği olmayan akranlarına kıyasla okuma, yazma, matematik, öğrenilen bilgileri genelleme, dil ve konuşma gibi alanlarda güçlükler yaşamaktadır (Gargiulo ve Bouck, 2018; Sucuoğlu, 2017). Bu güçlüklerin bazıları öğrenci kaynaklı olabileceği gibi bazıları da eğitim, aile ve öteki sosyal ortamlarında öğrenmeyi etkileyen çeşitli faktörlerden kaynaklı olabilmektedir. Öğretmenlerin zihin yetersizliği olan öğrencilerin öğrenme süreçlerine yönelik tutumları, öğrencilerden beklentileri, öğrenme imkanlarına ulaşım, eğitim ortamı, aile katılımı ve okul yönetiminin tutumu bu öğrencilerin öğrenme sürecini etkileyebilecek başlıca faktörlerdir.

Okuma, zihin yetersizliği olan öğrencilerin güçlük yaşadı̆̆ı akademik beceri alanlarından birisidir. Geçmiş çalışmalar zihin yetersizliği olan öğrencilerin diğer öğrencilere kıyasla daha düşük okuma becerisine sahip olduğunu göstermiştir. Örneğin, Schulte vd. (2016) genel eğitim ve özel eğitim öğrencilerinden oluşan yaklaşık yüz bin öğrencinin üçüncü sınıftan yedinci sınıfa kadar olan okuma gelişimlerini incelemiştir. Araștırmacılar zihin yetersizliği olan öğrencilerin genel eğitim öğrencilerine ve diğer özel gereksinimli öğrencilere kıyasla tüm yıllarda daha düşük okuduğunu anlama performansı sergilediğini bulmuştur. Bir başka çalışmada Wei vd. (2011) 11 farklı özel eğitim sınıflandırma kategorisinden 7 ile 17 yaş arası 3,421 öğrencinin okuma becerilerinin zaman içerisindeki gelişimini incelemiştir. Araştırmacılar diğer tüm özel gereksinimli öğrencilere kıyasla zihin yetersizliği olan öğrencilerin harf-kelime tanıma ve okuduğunu anlamada daha düşük performansa sahip olduğunu belirtmiştir. Aynı kategori içine konumlansa da zihin yetersizliği olan öğrenciler bireysel, sosyal ve çevresel özellikleri açısından geniş bir spektrumda yer alırlar. Zihin yetersizliği olan öğrenciler her ne kadar düşük okuma performansına sahip olsalar da bu öğrencilerin düşük okuma performansını sadece onların bireysel öğrenme süreci ve kapasitesi ile ilişkilendirmek doğru olmayacaktır. Zihin yetersizliği olan öğrencilere yönelik okuma müdahalelerinin kim tarafından, hangi yöntem ve materyaller kullanılarak, hangi ortamda, kimlerin desteğiyle, hangi kurallar ile uygulandığının da belirlenmesi gerekmektedir. Okuma, bireysel bir etkinlik olduğu gibi aynı zamanda sosyal, kültürel ve tarihsel bir yapıya da sahiptir (Hassett, 2008). Bu derlemenin amacı zihin yetersizliği olan öğrencilere uygulanan okuma müdahalelerinin kültürel-tarihsel bir incelemesini sunmaktır. Gelecek bölümlerde zihin yetersizliği ile tanımlanan öğrencilere okuma öğretiminin kısa bir tarihinden ve incelenecek çalışmalara kuramsal bir çerçeve getirmesi amacıyla Kültürel-Tarihsel Etkinlik Kuramından bahsedilmiştir.

\section{Zihin Yetersizliği Olan Öğrencilere Okuma Öğretiminin Kısa Bir Tarihi}

Zihin yetersizliği olan öğrencilere okuma öğretimi özel eğitim alanında uzun bir geçmişe sahiptir. Katims (2000) ilk sistematik öğretim uygulamalarının 19. yüzyılın ilk yarısında Jean Marc-Gaspard Itard tarafından ağır düzeyde zihin yetersizliği olan Aveyron isimli 
Fransız bir çocuk için yapıldığını belirtmiştir. Itard bu ilk uygulamalarda çoklu duyusal kinestetik izleme, görsel sözcük, sistematik ve doğrudan öğretim yöntemlerini kullanmıștır. $\mathrm{Bu}$ ilk uygulamaların okuma öğretiminde başarılı olmadığı belirtilmiștir (Katims, 2000). Fakat Itard'ın öğrencisi olan Edouard Seguin, Itard'ın çalışmalarını geliştirmeye devam etmiştir. Katims (2000) Seguin'in zihin yetersizliği olan öğrencilerle çizgi çizme, alfabenin harflerini yazma, ahşaptan yapılmış harfleri alfabe kartları ile eşleştirme ve tek heceli kelime kartı okuma çalışmalarında başarılı olduğunu belirtmiştir.

20. yüzyıla gelindiğinde zihin yetersizliği olan çocuklara yönelik okuma eğitimi ile ilgili üç dönemin ortaya çıktığı görülmektedir. Birinci dönem 1970 ve öncesinde kabul gören gelişimsel yaklaşım dönemidir (Mirenda, 2003). Bu dönemin en önemli özelliği öğrencilerin temel görsel sözcükleri ve okumaya hazırlık becerilerini öğrenmeleri olmuştur. Örneğin, öğrencilere ilk önce ses-harf ilişkisi, sonra kelime bilgisi ve en son okuduğunu anlama gibi becerilerin aşamalı bir şekilde öğretiminin yapılması hedeflenmiştir. Orta ve ağır düzeyde zihin yetersizliği olan öğrencilerin çoğu alt düzey okuma becerilerini öğrenmede zorlandıkları için daha üst düzey okuma becerisi eğitimi alamamıștır (Copeland ve Keefe, 2007). Gelişimsel yaklaşımın okuma becerilerinin aşamalı bir şekilde öğretilmesi gerektiğini savunmasından dolayı zihin yetersizliği olan öğrenciler için okuma eğitimi yaşlarına ve sınıf düzeylerine uygun olamamıştır (Copeland ve Keefe, 2007). Sonuç olarak bu öğrenciler aynı okuma becerilerini yıllarca tekrar etmek zorunda kalmışlardır.

İkinci dönem, 1970'li yıllardan sonra ortaya çıan ve zihin yetersizliği olan öğrencilere işlevsel okuma yaklaşımının uygulandığı dönemdir. Özellikle, Wisconsin Üniversitesi'nden Lou Brown ve arkadaşlarının (Brown vd., 1970; Brown vd., 1972) öncülügünde işlevsel okuma öğretimine yönelik çalışmalar bu yöntemin etkililiğini göstermiştir. İşlevsel okumada öğrenciden bir kelimeyi fonetik ve yapısal özelliklerine bakmaksızın tanımlaması beklenmiștir. Öğrenciden kelimeyi tanımlamasına ek olarak o kelimeyi anladığını göstermesi için uygun nesnelere dokunması istenmiştir. Sözlü olmayan ve okunan kelimenin anlaşıldığını bildiren bu ek koşul işlevsel okuma olarak bilinmektedir (Brown vd., 1974). İşlevsel okuma yaklaşımı zihin yetersizliği olan öğrencilere okul ve toplumsal yașam da sıklıkla karşılaşılan görsel sözcüklerin öğretimini savunmuştur. Browder ve Xin (1998) tarafından yapılan bir meta analizinde bu yaklaşımın orta ve ağır düzeyde zihin yetersizliği olan öğrencilere okuma öğretiminde etkili olduğu bulunmuştur. Ancak bu yaklaşım, okuduğu metni anlama becerisine odaklanmamasından, sadece söz öbeği anlamayı öğretmeyi amaçladığından ve öğrencilere yaşlarına uygun bir eğitim firsatı sunmamasından dolayı yetersiz bulunmuştur (Copeland ve Keefe, 2007).

Üçüncü dönem, zihin yetersizliği olan öğrencilerin genel eğitim müfredatına maksimum erişimi ile ilgili uygulamaların ve beklentilerin arttığı dönemdir ve bu dönemin oluşmasına zemin hazırlayan toplumsal olaylar 1950'lere kadar dayanır. Özellikle Amerika Birleşik Devletleri'nde (ABD) 1950'li yıllarda ailelerin öncülügünde başlayan eğitimde fırsat eşitliği hareketi ile azınlıklar ve özel gereksinimli öğrenciler eğitim alanında tüm öğrenciler için eșit ve kapsayıcı eğitim gibi birçok kazanım elde etmişlerdir (örneğin Brown vs. Board of Education of Topeka, 1954). Bu kazanımlar temelinde, ABD'de son 20 yılda özel ve genel eğitim yasalarında bütün öğrencilerin genel eğitim müfredatına erişimi güvence altına alınmıştır. Örneğin, No Child Left Behind (NCLB, 2001), Individuals with Disabilities Education Act (IDEA, 2004) ve Every Student Succeds Act (ESSA, 2015) yasaları zihin yetersizliği olan öğrencilerin diğer bütün öğrenciler gibi genel eğitim müfredatından yararlanmasını ve merkezi sınavlara katılımlarını gerektirmiștir. Genel eğitim müfredatına erişim, zihin yetersizliği olan 
öğrencilere okuma eğitiminde içeriğin zenginleştirilmesine, kalitenin ve beklentinin artmasına katkı sağlamıştır. Zihin yetersizliği olan öğrencilerin sadece görsel sözcük öğrenmesi değil aynı zamanda okumada akıcılık ve okuduğunu anlama gibi üst düzey okuma becerilerine sahip olmaları hedeflenmiştir. Ayrıca, hafif ve orta düzeyde zihin yetersizliği olan öğrencilerin normal gelişim gösteren akranları gibi her eyaletin geliștirip uyguladığı genel okuma testlerine, ağır düzeyde zihin yetersizliği olan öğrencilerin alternatif okuma testlerine ve böylelikle bütün zihin yetersizliği olan öğrencilerin hesap verilebilirlik sistemine katılımı zorunlu tutulmuştur. Geçmiş çalışmalarda zihin yetersizliği olan öğrencilere sadece görsel sözcük öğretiminin yetersiz olduğu ve bu öğrencilerin okumada akıcılık ve okuduğunu anlama gibi üst düzey okuma becerilerini de içeren çok bileşenli okuma müdahalelerinde başarılı oldukları bulunmuştur (Afacan vd., 2018; Allor vd., 2014; Browder vd., 2012).

Tarihsel süreç izlendiğinde zihin yetersizliği olan öğrencilere yönelik uygulanan okuma müdahalelerinin dönemsel olarak değişikliklere uğradığı görülmektedir. Öğretimsel yaklaşımlardaki değișimlerle birlikte öğrencilerin okuma becerilerinin de gelişme gösterdiği gözlenmektedir. Sosyal çevre, okul ve öğretmen beklentilerine bağlı olarak zamanın öğrencilerin okuma becerilerini etkilediği (Compton-Lilly, 2012) ve okuma becerisinin kültürel ve tarihsel bağlamda gelişim gösteren bir beceri olduğu belirtilmiştir (Hassett, 2008). Okuma eğitimi ile ilgili çalışma yapan araştırmacıların, okumanın kültürel ve tarihsel yönüne yönelik yaptıkları bu vurgu Kültürel-Tarihsel Etkinlik Kuramının zihin yetersizliği olan öğrencilere yönelik uygulanan okuma müdahalelerini incelemek için bir çerçeve oluşturabileceğini göstermektedir. Ayrıca genel eğitim müfredatına erişim ve kapsayıcı eğitim uygulamaları farklı yöntemler, araç gereçler, kişiler, kurallar, ortamlar ve iş bölümü gibi çok bileșenli bir yapıya sahiptir. Bu yüzden analiz biriminin öğrencinin sahip olduğu bireysel becerilerden öğretmenin kullandığı öğretimsel araç gereçlere, öğrencinin dahil olduğu okuma etkinliklerine ve eğitim ortamının sosyal ve kültürel bağlamına genişletilmesi gerekmektedir. KültürelTarihsel Etkinlik Kuramı çevre ve insan ilişkisini gösteren ve çok bileşenli sistemsel bir analiz yapmaya olanak sağlayabilecek kuramsal bir çerçeveyi sunabilmektedir.

\section{Kültürel-Tarihsel Etkinlik Kuramı}

Kültürel-Tarihsel Etkinlik Kuramı (Cultural-Historical Activity Theory), Lev Vygotsky'nin (1978) ve takipçilerinin insanların öğrenme davranışları ve psikolojik gelişimleri üzerine geliştirdiği düşüncelerinden ortaya çıkan bir kuramdır. Bu kurama göre insanın psikolojik gelişimi kültürel-tarihsel olarak gelişen ve pratik etkinliklerden oluşan bir süreç olarak tanımlanmıştır. Kültür, bir topluluğun birlikte problem çözme etkinlikleri ve değișen şartlara uyum sağlamak için kullandıkları tarihsel süreçte biriken tüm araç gereçler olarak ifade edilmektedir (Cole, 1996). Vygotsky, bireylerin (subjects) bir takım kültürel araç gereçleri (artifacts) kullanarak hedef (object) üzerinde bir değişiklik yapmayı amaçladıklarını belirtmiştir.

Vygotsky'nin geliştirdiği bu kuram sonraki yıllarda takipçileri tarafından geliştirilmeye devam edilmiştir. Vygotsky çalışmalarında bireyin kültürden gelen düşünce ve maddeleri (artifacts) kullanarak çevresini ve kendi davranışlarını nasıl değiştirdiğini anlamaya çalışırken, yeni kuşak Kültürel-Tarihsel Etkinlik Kuramı çalışmaları, kişilerin toplu olarak yaptıkları etkinlikleri analiz etmeyi ve yeniden düzenlemeyi hedeflemiştir (Bal, 2018). Yeni kuşak araștırmacılar, özne (subject), araç gereçler (artifacts), hedef (object) üçlüsünden oluşan analiz birimine, kurallar (rules), topluluk (community) ve iş bölümü (division of labor) ögelerini ekleyerek kolektif etkinlik sisteminin önemini vurgulamıştır (Cole, 1996; Engeström, 1987). Hedef (object) temelli 
çalışmalar etkinlik sistemini birlikte tutan en önemli unsur olarak belirtilmiştir. Öğrenme süreci hedefin ilerlemesi veya gelişmesi olarak tanımlanmıştır. Öğrenme çıktısı olarak hedefin gelişmesi eğitim araștırmalarında dönüşüme katkı sağlayacak önemli bir durum olarak belirtilmiştir. Yrjö Engeström, Kültürel-Tarihsel Etkinlik Kuramının gelişmesine katkı sağlayan önemli araştırmacılardan biridir. Engeström (1987; 2016), hedefin (object) birden fazla sisteminin (aile, okul vb.) kesişim noktasında yer aldığını belirtmiştir. Bağımsız etkinlik sistemleri hedef (object) aracılığı ile birbirine bağlı hale gelmektedir. Hedefin gelişmesi ve ilerlemesi çoklu etkinlik sistemlerinin bölümlerinin herhangi bir çelişki (contradiction) yaşamamasına bağlıdır. Etkinlik sistemlerinde yaşanabilecek olası çelişkiler hedef (object) üzerinde istenmedik öğrenme çıktılarına sebep olabilmektedir.

Bilişsel ve davranışsal öğrenme kuramlarında öğrenme süreci kișilerin kendi kendilerine ya da dışsal uyaranlara bağlı olarak düşünce ve davranışlarında gerçekleştirecekleri değişimler olarak tanımlanmıştır. Ancak Kültürel-Tarihsel Etkinlik Kuramı öğrenme sürecinin kişinin çevresi ve kültürün bilişsel süreci destekleyen araç gereçleri ile kurduğu etkileşimlere bağlı olarak geliștiğini vurgulamaktadır. Gelişim, bir alan ile ilgili yapılan etkinliklerin kişiler tarafından içselleşmesi sonucu ortaya çıkmaktadır. Bir beceriyi içselleştirme ve o beceride bağımsızlaşma toplumsal alanlarda kazanılacak deneyimler ya da etkileşimler sayesinde olabilecektir. Okumayı öğrenme süreci de bu bağlamda gerçekleşebilmektedir. Örneğin; öğrencilerin okuma becerileri (outcomes), öğretimi kimin yaptığı (subjects), kullanılan yöntem ve araç-gereçler (artifacts), kurallar (rules), öğretim ortamı (community) ve iş bölümünün (division of labor) çalışma etkililiğine bağlı olarak gelişebilmektedir. Ayrıca okul, aile, yasalar ve toplum gibi farklı etkinlik sistemlerinin çelişkilere (contradictions) neden olmaması öğrencilerin okuma başarılarına doğrudan katkı sağlayacaktır. Kültürel-Tarihsel Etkinlik Kuramında belirtilen etkinlik sisteminin şeması Şekil 1'de gösterilmektedir.

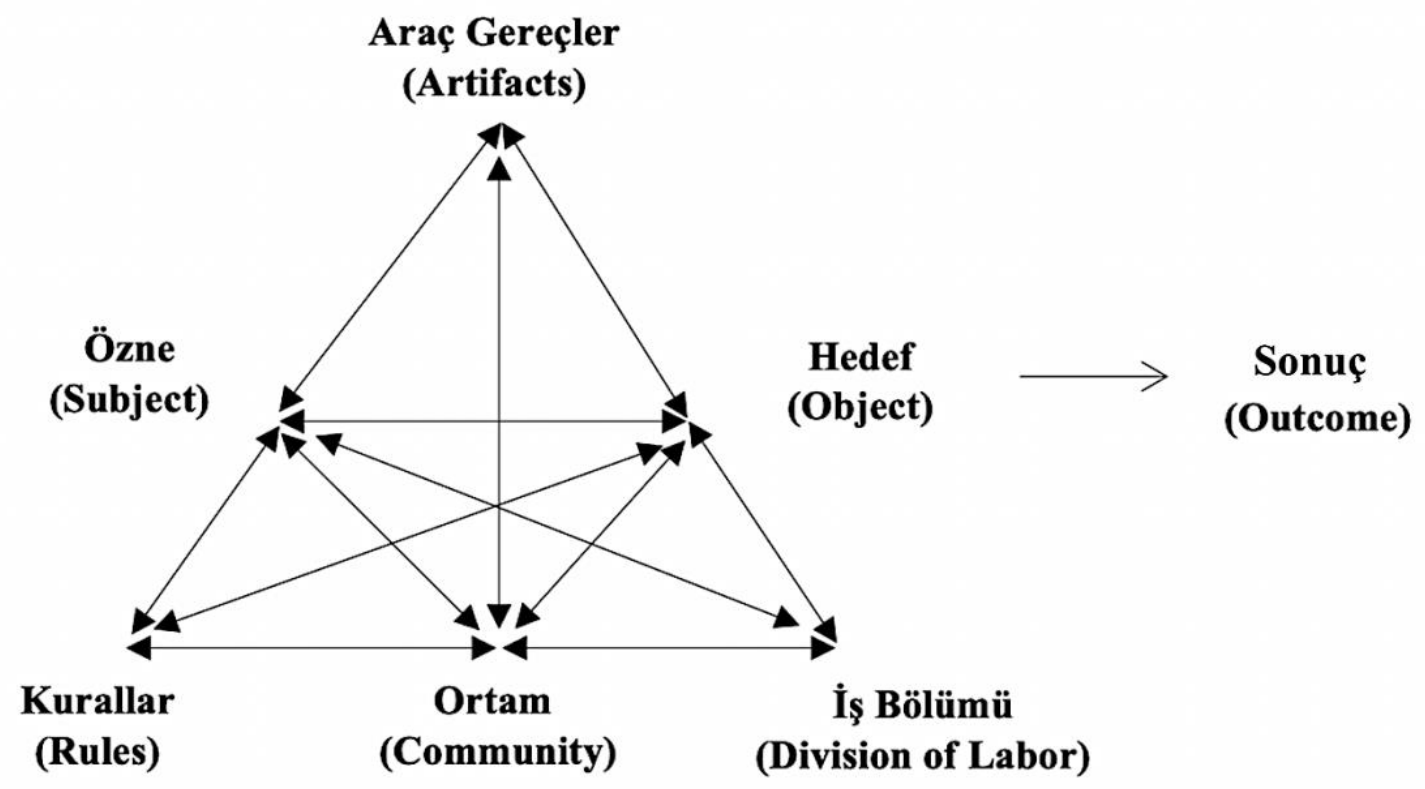

Şekil 1. Kültürel-Tarihsel Etkinlik Kuramı sistemi

Kültürel-Tarihsel Etkinlik Kuramı, dünyada eğitim araştırmalarında giderek yaygınlaşmakta ve araştırmacılar tarafından tasarlanan ve yönetilen mesleki gelişim atölye verilerini geriye dönük olarak analiz etmek için sıklıkla kullanılmaktadır. 
Yamagata-Lynch ve Haudenschild (2009) ABD'de sistemsel analiz yapan birçok nitel araştırmada etkinlik sistemleri analizinin ek bir araç olarak kullanıldığını belirtmiştir. Eğitim araștırmacıları, öğretmenlerin mesleki gelişimini ve toplumdaki uygulamaları nasıl iyileştireceklerine dair fikirler üretmek için etkinlik sistemleri analizini çalışmalarında kullanmaktadır. Ayrıca Waitoller ve Kozleski (2013) kapsayıcı eğitim reformu geliștirmeye odaklanan okullar ve üniversiteler arasındaki ortaklıklarda karşılaşılan engelleri incelemek ve ortaya çıarmak için Kültürel-Tarihsel Etkinlik Kuramını kullanmıştır. Buradan Kültürel-Tarihsel Etkinlik Kuramının hem sistemsel bir analiz aracı hem de bir perspektif olarak eğitim alanında kullanılabilecek bir çerçeve olduğu görülmektedir.

Kültürel-Tarihsel Etkinlik Kuramının bir analiz aracı ve perspektif olarak kullanılabilmesinin yanı sıra, işyerlerinde ve eğitim ortamlarında sistemsel dönüşüm için bir yöntem olarak da kullanılabilmektedir. Biçimlendirici müdahale (formative intervention) adı verilen bu sistemsel dönüştürme aracı Kültürel-Tarihsel Etkinlik Kuramının sunduğu yeni bir yöntemdir. Uygulayıcıların, sosyal ve kişisel yaşam zorluklarını çözmek ve etkinlik sistemlerine yeniden aracılık etmek için araştırmacılarla beraber çalıştıkları bu sistemsel müdahaleler (Engeström, 2008) 1990'lardan bu yana sağlık, tarım, medya ve eğitim gibi alanlarda yeni tasarımlar oluşturmak için etkili bir şekilde kullanılmaktır (Bal, 2018; Sannino vd., 2009). Eğitim alanında ise sistem ve tasarım temelli araștırmadaki sorunları ele almak için biçimlendirici müdahalelerin ihtiyaç duyulan bir yaklaşım olduğu belirtilmiştir (Gutiérrez ve Penuel, 2014; Penuel, 2014; Sannino vd., 2009).

\section{Çalışmanın Amacı}

Özellikle son on yılda Kültürel-Tarihsel Etkinlik Kuramı ABD, Finlandiya, Avustralya, Danimarka, İsveç, Güney Afrika, Japonya, Çin, Tayvan ve Brezilya gibi ülkelerde eğitim, organizasyon psikolojisi, tıp eğitimi, halk sağlığı, bilgisayar ve endüstri mühendisliği, tarım gibi çeşitli alanlarda çok yoğun ilgi görmektedir. Etkinlik kuramı, Türkiye'de özel eğitim alanında, araştırmacılar, öğretmenler, psikologlar ve diğer paydaşların birey-çevre ilişkisini kavraması ve çevreye uygun müdahale yöntemleri geliştirmesi için yararlı olabilir. Bu çalışmada, Kültürel-Tarihsel Etkinlik Kuramı bağlamında zihin yetersizliği olan öğrencilere yönelik uygulanan okuma müdahalelerinde öğretim sürecini etkileyen faktörlerin ortaya çıkarılması amaçlanmıştır.

\section{Yöntem}

\section{Veri Toplama Süreci}

Bu çalışmanın verileri Türkiye'de yayın yapan dergilerin elektronik arşivlerinde tespit edilen çalışmalardan toplanmıştır. Veri toplamak için TR Dizin (ULAKBIM) veri tabanı kullanılmıștır. TR Dizin, TUBİTAK ULAKBİM tarafından geliștirilen ve Türkiye adresli bilimsel dergilerin uluslararası standartlara uygun hale getirilmesini amaçlayan bir veri tabanıdır. Veri tabanında arama yapmak için üç farklı seviyede anahtar kelimeler kullanılmıştır:

- (Seviye 1) okuma öğretimi OR okuma müdahalesi OR reading instruction OR reading intervention

- (Seviye 2) okuduğunu anlama OR reading comprehension OR akıcı okuma OR fluency OR kelime OR vocabulary

- (Seviye 3) zihin engelli OR zihinsel yetersizlik OR zihin yetersizliği OR zihinsel engelli OR intellectual disability OR cognitive disability OR mental retardation. 
$\mathrm{Bu}$ anahtar kelimelerle TR Dizin veri tabanında ilk olarak toplam 472 sonuç elde edilmiştir. Makalelerin başlık ve özleri incelenmiştir. Tespit edilen 472 makaleden yedisinin zihin yetersizliği olan öğrencilere okuma öğretimi konusu ile ilgili olduğu tespit edilmiştir (Akoğlu ve Turan, 2012; Atik-Çatak ve Tekinarslan, 2008; Çetrez-İşcan ve Coşkun, 2016; Işılkdoğan ve Kargın, 2010; Özak ve Avcıŏlu, 2012; Güzel-Özmen, 2011; Şengül ve Akçin, 2010). Derlemenin kapsamını genişletmek için eğitim alanında yayın yapan 24 derginin elektronik arşivleri incelenmiştir. Tablo 1'de incelenen 24 derginin isimleri, incelenen yıllar ve her bir dergide bu çalışmanın konusu ile ilgili bulunan toplam makale sayısı belirtilmiştir. Her bir derginin elektronik arşivi ilk yayın yılı ve sayısından (1976, Eğitim ve Bilim Dergisi) 2019 Aralık sayılarına kadar tek tek incelenmiştir. Bu ek incelemenin ardından konu ile ilişkili 14 (11'i yeni 3'ü daha önce bulunan) makale tespit edilmiştir. Şekil 2'de makale arama süreci belirtilmiştir.

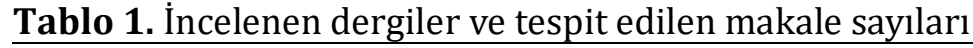

\begin{tabular}{lcc}
\hline Dergi Adı & $\begin{array}{c}\text { İncelenen } \\
\text { Ylllar }\end{array}$ & $\begin{array}{c}\text { Bulunan } \\
\text { Makale Sayısı }\end{array}$ \\
\hline 1. Abant İzzet Baysal Üniversitesi EFD & $2001-2019$ & 2 \\
2. Anadolu Journal of Educational Sciences International & $2011-2019$ & 0 \\
3. Ankara Üniversitesi Eğitim Bilimleri Fakültesi Özel Eğitim & $1992-2019$ & 8 \\
$\quad$ Dergisi & $2012-2019$ & 0 \\
4. Bartın Üniversitesi EFD & $2012-2019$ & 0 \\
5. Cumhuriyet Uluslararası Eğitim Dergisi & $2012-2019$ & 0 \\
6. Çukurova Üniversitesi EFD & $2001-2019$ & 0 \\
7. Ege Eğitim Dergisi & $1976-2019$ & 0 \\
8. Eğitim ve Bilim & $2002-2019$ & 0 \\
9. Erzincan Üniversitesi EFD & $2001-2019$ & 0 \\
10. Gazi Üniversitesi Gazi EFD & $1986-2019$ & 1 \\
11. Hacettepe Üniversitesi EFD & $2009-2019$ & 0 \\
12. International Journal of Early Childhood Special Education & $2002-2019$ & 1 \\
13. İlköğretim Online & $2007-2019$ & 0 \\
14. İnönü Üniversitesi EFD & $2006-2019$ & 0 \\
15. Kastamonu Üniversitesi Kastamonu Eğitim Dergisi & $2008-2019$ & 1 \\
16. Kuramsal Ĕgitimbilim Dergisi & $1989-2019$ & 1 \\
17. Marmara Üniversitesi Atatürk Eğitim Fakültesi Eğitim & & \\
Bilimleri Dergisi & $2009-2019$ & 0 \\
18. Mehmet Akif Ersoy Üniversitesi EFD & $2005-2019$ & 0 \\
19. Mersin Üniversitesi EFD & $1987-2019$ & 0 \\
20. Ondokuz Mays Üniversitesi EFD & $1996-2019$ & 0 \\
21. Pamukkale Üniversitesi EFD & $2011-2019$ & 0 \\
22. Sakarya University Journal of Education & $2011-2019$ & 0 \\
23. Trakya Üniversitesi EFD & $1999-2019$ & 0 \\
24. Uludağ Üniversitesi EFD & & \\
\hline Not. Dergismerita & & \\
\hline
\end{tabular}

Not. Dergi isimleri alfabetik olarak sıralanmıştır. EFD= Eğitim Fakültesi Dergisi.

\section{Derleme Ölçütleri}

İncelemeye dahil edilecek makaleler için araştırmacılar tarafından dört ölçüt belirlenmiştir. İlk ölçüt, makalelerin okuma öğretimine yönelik bir uygulamayı betimlemesi olarak belirlenmiştir. İlk ölçütü karşılaması için araştırmacıların çalışmalarda nicel ya da tek denekli araştırma yöntemlerini kullandıklarını belirtmeleri aranmıştır. İkinci ölçüt olarak okuma öğretiminin zihin yetersizliği olan bir öğrenciye yönelik yapılması belirlenmiştir. Üçüncü ölçüt olarak ise çalışmaların TR dizin (ULAKBİM) veri tabanında yayın yapan bir dergide yayınlanması belirlenmiştir. Son ölçüt, makalelerin yazım dilinin Türkçe ya da İngilizce olması olarak belirlenmiştir. Bu 
ölçütlerin dışında kalan makaleler incelemeye alınmamıştır. Derleme ölçütleri tespit edilen çalışmalara uygulanmıştır. Akçin (2019) ve Güldenoğlu (2008) derleme, Başal ve Batu (2002), Kurtdere-Fidan ve Akyol (2011) ve Çetrez-İscan ve Coşkun (2016) nitel, Akçin (2006) ve Şengül ve Akçin (2010) betimsel yöntemleri kullandıkları için bu yedi makale derlemeye dahil edilmemiştir. Toplamda derleme ölçütlerini karşılayan 11 makale belirlenmiştir.

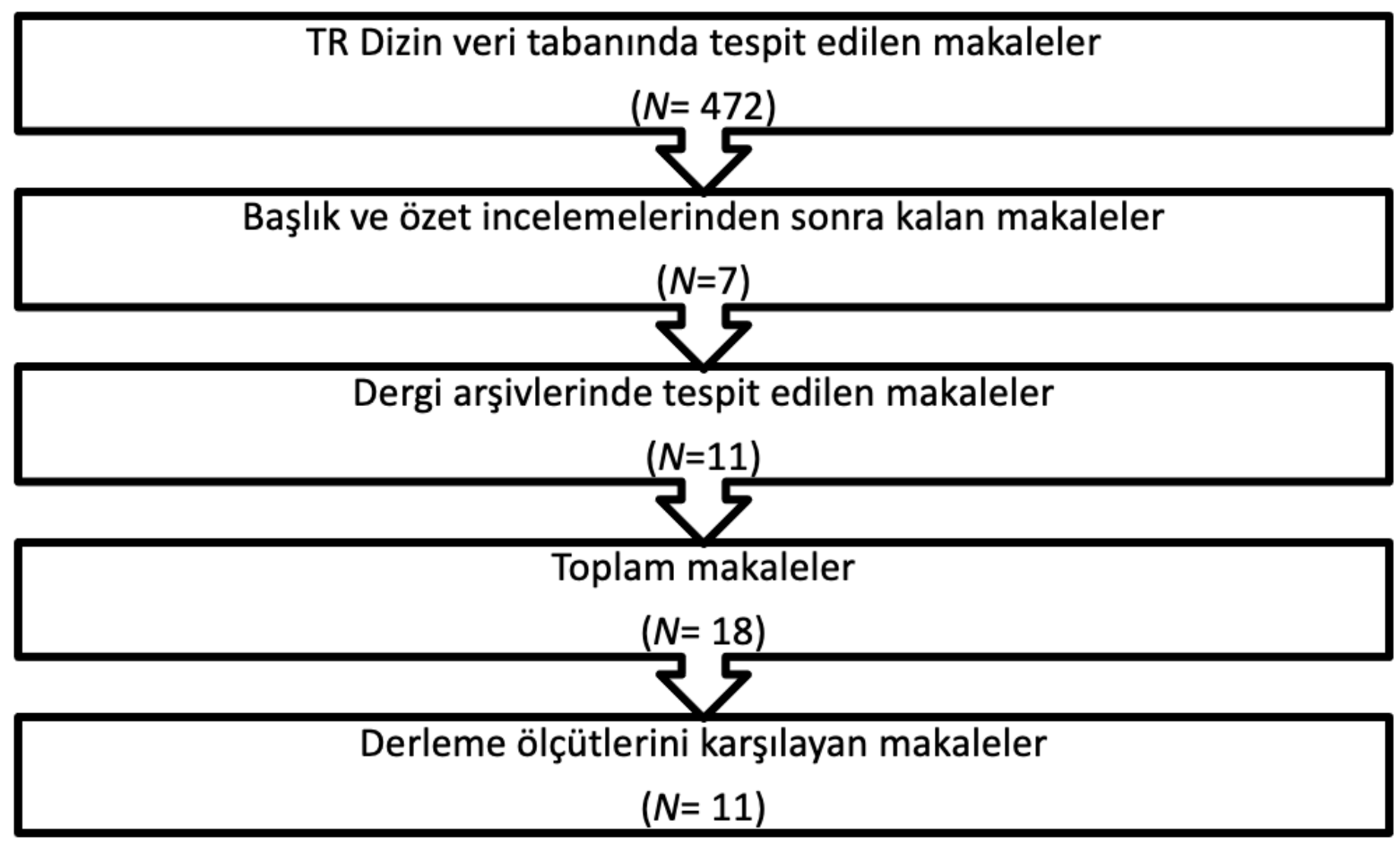

Şekil 2. Makale arama süreci

\section{Kodlama}

Tespit edilen 11 makale için Kültürel-Tarihsel Etkinlik Kuramı bağlamında yedi kodlama kategorisi kullanılmıştır. Bu kodlama kategorileri şunlardır: Özne (subject), araç gereçler (artifacts), hedef (object), iş bölümü (division of labor), kurallar (rules), ortam (community) ve sonuç (outcome). Özne (subject), okuma müdahalesini uygulamada kim ya da kimlerin görev aldığını (örneğin öğretmen, aile, araştırmacı); araç gereçler (artifacts), okuma müdahalesinde kullanılan yöntem ve çeşitli araç gereçleri (örneğin doğrudan öğretim, hikaye haritası, strateji öğretimi); hedef (object), okuma müdahalesinin kimi hedef aldığını (örneğin bütün sınıf, küçük grup, bireysel); iş bölümü (division of labor), uygulamada görev alanların görev dağılımını (örneğin işbirlikçi öğretim, uygulama güvenirliği); kurallar (rules), uygulamanın hangi kurallar altında uygulandığını (örneğin süre, oran, pekiştireç); ortam (community), uygulamanın hangi ortamda gerçekleştiğini (örneğin ayrı sınıf, kaynak oda, genel eğitim sınıfı); ve sonuç (outcome), uygulama sonucunda ne tür çıtıların elde edildiğini (örneğin okumada akıcılık, okuduğunu anlama, kelime bilgisi) ifade etmektedir. Her bir çalışmayı değerlendirmek için kullanılan kodlama kategorileri ve sonuçlar Tablo 2'de sunulmuştur. 
Tablo 2. Kültürel-Tarihsel Etkinlik Kuramı bağlamında incelenen çalıșmalar

\begin{tabular}{|c|c|c|c|c|c|c|c|}
\hline Makale & Uygulayıcı & Araç gereçler & Hedef & Kurallar & İş bölümü & Ortam & Sonuç \\
\hline $\begin{array}{l}\text { Akoğlu ve } \\
\text { Turan (2012) }\end{array}$ & Araştırmacı & $\begin{array}{l}\text { Ses bilgisel } \\
\text { farkındalık } \\
\text { becerileri eğitim } \\
\text { programı }\end{array}$ & $\begin{array}{l}\text { Hafif düzey } \\
\text { zihin } \\
\text { yetersizliği } \\
\text { olan } 12 \\
\text { öğrenci }\end{array}$ & $\begin{array}{l}\text { Program her çocuk için kesintisiz } \\
\text { olarak ve günde } 45 \text { 'er dakikalık } \\
\text { bireysel eğitim oturumları şeklinde } \\
\text { uygulanmıştır. Program aşamaları } \\
\text { basitten karmaşığa kolaydan zora } \\
\text { doğru sıralanmıştır. Bir aşama } \\
\text { tamamlanmadan bir sonraki } \\
\text { aşamaya geçilmemiştir. Her } \\
\text { oturum sonunda değerlendirme } \\
\text { yapılmıştır. }\end{array}$ & $\begin{array}{l}\text { Araştırmacı - } \\
\text { uygulayıcı } \\
\text { Öğrenci - } \\
\text { öğrenen }\end{array}$ & $\begin{array}{l}\text { Özel eğitim ve } \\
\text { rehabilitasyon } \\
\text { merkezi } \\
\text { Birebir öğretim }\end{array}$ & $\begin{array}{l}\text { Kontrol ve uygulama grubu } \\
\text { öğrencileri arasında uyak } \\
\text { farkındalığı, hece harf becerileri, } \\
\text { sesbirim farkındalığı, harfleri } \\
\text { isimlendirme becerileri, ses } \\
\text { bilgisel farkındalı, metni } \\
\text { toplam okuma süresi, okuma } \\
\text { hataları sözcükleri birbirinin } \\
\text { yerine koyma ve okuma } \\
\text { hatalarını düzeltme becerileri } \\
\text { açısından anlamlı farklar } \\
\text { bulunmuştur. }\end{array}$ \\
\hline $\begin{array}{l}\text { Atik-Çatak ve } \\
\text { Tekinarslan } \\
(2008)\end{array}$ & Araştırmacı & $\begin{array}{l}\text { PowerPoint, } \\
\text { kelime, cümle ve } \\
\text { metni anlama } \\
\text { materyalleri } \\
\text { Veri kayıt formları }\end{array}$ & $\begin{array}{l}\text { Hafif düzey } \\
\text { zihin } \\
\text { yetersizliği } \\
\text { olan } 3 \\
\text { öğrenci }\end{array}$ & $\begin{array}{l}\text { Öğrenciler sunuda gördüğü } \\
\text { kelimeleri okumuş, okuduğu } \\
\text { kelimeyi anlatan resmi bulmuş, } \\
\text { sunuda yer alan cümleleri okuma } \\
\text { ve soruları cevaplamış, resimleri } \\
\text { yorumlamış, metni sesli okumuş, } \\
\text { resimleri takip ederek metindeki } \\
\text { olayı anlatmış ve soruları } \\
\text { cevaplamıştır. }\end{array}$ & $\begin{array}{l}\text { Araştırmacı - } \\
\text { uygulayıcı } \\
\text { Öğrenci - } \\
\text { öğrenen }\end{array}$ & $\begin{array}{l}\text { Kaynaştırma } \\
\text { Sinıfı }\end{array}$ & $\begin{array}{l}\text { Uygulamadan sonra } \\
\text { öğrencilerin kelimeyi anlama } \\
\text { düzeylerinde } \% 10-20 \text {, cümleyi } \\
\text { anlama düzeyleri arasında } \% 30 \text { - } \\
50 \text { ve metni anlama düzeyinde } \\
\% 40 \text { artış olmuştur. }\end{array}$ \\
\hline $\begin{array}{l}\text { Demir ve } \\
\text { Doğanay-Bilgi } \\
\text { (2018) }\end{array}$ & Araştırmacı & $\begin{array}{l}\text { Yazıca } \\
\text { zenginleștirilmiş } \\
\text { oyunlar } \\
\text { Okul öncesi } \\
\text { dönemde sözcük } \\
\text { ve yazı } \\
\text { farkındalığı } \\
\text { değerlendirme } \\
\text { aracı }\end{array}$ & $\begin{array}{l}\text { Hafif düzey } \\
\text { zihin } \\
\text { yetersizliği } \\
\text { olan } 3 \\
\text { öğrenci }\end{array}$ & $\begin{array}{l}\text { Öğretim her öğrenci için } 8 \text { oturum } \\
\text { sürmüş ve her bir oturumda bir } \\
\text { oyun oynanmıştır. Oyun } \\
\text { sıralamaları her bir denek için } \\
\text { aynıdır. Araştırmacı her bir yazı } \\
\text { farkındalığı becerisi için model } \\
\text { olmuş öğrenciden tepki istemiştir. } \\
\text { Doğru tepkiler pekiştirilmiş } \\
\text { yanlışlar ise yeniden öğretilmiştir. }\end{array}$ & $\begin{array}{l}\text { Araştırmacı - } \\
\text { uygulayıcı } \\
\text { Öğrenci - } \\
\text { öğrenen } \\
\text { Özel eğitim } \\
\text { öğretmeni- } \\
\text { uygulama } \\
\text { güvenirliği }\end{array}$ & $\begin{array}{l}\text { Okullardaki } \\
\text { ayrı (boş) } \\
\text { sinıflar }\end{array}$ & $\begin{array}{l}\text { Başlama düzeyine göre yazıca } \\
\text { zenginleştirilmiş oyun ile yazı } \\
\text { farkındalığı becerileri öğretimi } \\
\text { sonunda öğrencilerin aldıkları } \\
\text { puanlar birinci öğrenci için } \\
18,75 \text { puan, ikinci öğrenci için } \\
\text { 17,75 puan ve üçüncü öğrenci } \\
\text { için } 20,66 \text { puan artış } \\
\text { göstermiştir. }\end{array}$ \\
\hline $\begin{array}{l}\text { Duman ve Çifci } \\
\text {-Tekinarslan } \\
(2007)\end{array}$ & Araştırmacı & $\begin{array}{l}\text { Hikâye haritası } \\
15 \text { Hikâye } \\
\text { Okuduğunu } \\
\text { anlama ölçü } \\
\text { araçları }\end{array}$ & $\begin{array}{l}\text { Hafif düzey } \\
\text { zihin } \\
\text { yetersizliği } \\
\text { olan } 3 \\
\text { öğrenci }\end{array}$ & $\begin{array}{l}\text { Öğrenciler her oturumda aynı } \\
\text { öğelerden oluşan farklı hikayeler } \\
\text { okumuştur. } \\
\text { Öğrencilerin sorulara \%80 doğru } \\
\text { yanıt vermesi beklenmiştir. }\end{array}$ & $\begin{array}{l}\text { Araştırmacı - } \\
\text { uygulayıcı } \\
\text { Öğrenci - } \\
\text { öğrenen }\end{array}$ & $\begin{array}{l}\text { Özel eğitim } \\
\text { sinıfı } \\
\text { Birebir öğretim }\end{array}$ & $\begin{array}{l}3 \text { öğrencinin de okuduğunu } \\
\text { anlama sorularına verdikleri } \\
\text { cevapların yüzdesi \%88-100 } \\
\text { olarak raporlaştırılmıştır. }\end{array}$ \\
\hline
\end{tabular}


Güldenoğlu ve Kargin (2012)

Güzel-Özmen Araștırmac (2011)

Güzel-Özmen ve Vayiç (2007)
Araștırmacl

Okuduğunu anlama becerisi için okuma metinleri, Video

kamera, CD, Sesli okuma testi, veri toplama formları

Okuma metinleri ve karşılaştırma șeması

Kayıt çizelgesi tepkiler, yanlıs tepkiler, tepkide yetersizliği bulunmama ve 15 gün sonra

ögrenci

Zihin olan 5

öğrenci

öğrencilere sessiz okutulmuş v benzerlik ve farklılıklar üzerine

sorular sorularak kararlılık

sağlanmıştır. Karşılaştırma şemas ögrenciye tanıtıldıktan sonra okuma yapilarak șema doldurturmustur.
Hafif düzey Öğrencilerden bağımsız doğru olan 3 izleme verileri toplanmıștır.

Araştırmacl-

Ögrenci -

öğrenen

Anne-sosyal

geçerlikle ilgili

görüşler

Araștırmacl

gözlemciler ve

öğrenciler

odas

gitim ve

rehabilitasyon

merkezi

Birebir öğretim

ogrencin de okuduğu metni

özetleme ile ilgili becerilerin

hepsine doğru tepki verdiği

bulunmuștur.

4 öğrencide, metinde bulunan benzerlikler ve farklılıklar hatırlamada şematik

düzenleyiciyi okuma sonras doldurma, okuma öncesi şematik düzenleyicinin sunumuna göre daha etkil olmuștur. 1 öğrencide ise şematik düzenleyicinin okuma öncesi sunumu daha etkili

olmus, farklılıkları hatırlamada ise sunumların etkililiğ $\mathrm{i}$

farklılaşmamış her iki sunumda etkili olmuștur. zihin bașlamadan önce uygulanmıștır.

Tartısma, model

olma, rehberli

ağımsız

uygulamalar

Fişler, kendini

izleme tablosu,

resimli kartlar
Hafif düzey Tartışma, model olma oturumuna

Öğretmen-

yetersizliğ

olan 3

öğrenci Model olmada araștırmacı strateji

uygulayıc

Özel eğitim

Uygulamadan sonra

ögrencilerin tümü fiș hecelerini

$\% 100$, kelimeleri \%88- \%100 ve cümle içindeki kelimeleri \%88-

\%100 oranında doğru

yüksek sesle ve uygulayarak model Arastırma

olmus, rehberli uygulamalarda

strateji kullanımına öğrenciye

görevlileri-

okumuslardır. er olmuș ve geri dönütler

uygulama

güvenirliği vermistir. Bağmsiz uygulamalarda öğrenciden bağımsız olarak strateji basamaklarını gerçekleştirmesi istenmistir. 


\begin{tabular}{|c|c|c|c|c|c|c|c|}
\hline $\begin{array}{l}\text { Işıkdoğan ve } \\
\text { Kargın (2010) }\end{array}$ & Araștırmacı & $\begin{array}{l}\text { Hikâye haritası } \\
\text { şema formu, } \\
\text { izleme formu, } \\
\text { hikâye anlama } \\
\text { formu, Sesli } \\
\text { okuma testi ve } \\
\text { öğretmen } \\
\text { görüşme formu }\end{array}$ & $\begin{array}{l}\text { Hafif düzey } \\
\text { zihin } \\
\text { yetersizliği } \\
\text { olan } 14 \\
\text { öğrenci }\end{array}$ & $\begin{array}{l}\text { Bireysel olarak her öğrenciye } \\
\text { seçilen hikâye okutularak } 8 \\
\text { bileşenli okuduğunu anlama } \\
\text { soruları sorulmuştur. Öğretim } \\
\text { oturumlarında her öğrenci ile } \\
\text { hikâye haritası tekniği aşamaları } \\
\text { (model olma, rehberlik, test, } \\
\text { süreklilik) takip edilmiştir. }\end{array}$ & $\begin{array}{l}\text { Araştırmacı, } \\
\text { öğretmen, } \\
\text { öğrenciler }\end{array}$ & $\begin{array}{l}\text { Devlet okulu ve } \\
\text { özel eğitim } \\
\text { merkezi Birebir } \\
\text { ögretim }\end{array}$ & $\begin{array}{l}\text { Okuduğunu anlamada hikâye } \\
\text { haritası tekniği kullanılarak } \\
\text { yapılan öğretim oturumlarının, } \\
\text { bu uygulamaya katılan } \\
\text { öğrencilerin anlama } \\
\text { düzeylerinde olumlu bir artış } \\
\text { yarattığı gözlemlenmiştir. }\end{array}$ \\
\hline $\begin{array}{l}\text { Kurcaali-İftar ve } \\
\text { Uysal (1999) }\end{array}$ & $\begin{array}{l}\text { Öğretmen } \\
\text { Özel eğitim } \\
\text { danışmanı }\end{array}$ & $\begin{array}{l}\text { Resimli fişlerle } \\
\text { okuma öğretimi }\end{array}$ & $\begin{array}{l}\text { Hafif düzey } \\
\text { zihin } \\
\text { yetersizliği } \\
\text { olan } 4 \\
\text { öğrenci }\end{array}$ & $\begin{array}{l}\text { Her sözcüğe karşılık tek bir resim } \\
\text { seçilmiştir. Öğrencinin resmin neyi } \\
\text { temsil ettiğini tahmin etmesine } \\
\text { izin verilmemiştir. Resimli fiş } \\
\text { öğretmenin benimsediği öğretim } \\
\text { yöntemiyle öğretilmiştir. Resmi } \\
\text { geciktirme uygulaması ve resimsiz } \\
\text { okuma yapılmıştır. }\end{array}$ & $\begin{array}{l}\text { Özel eğitim } \\
\text { danışmanı- } \\
\text { bireysel } \\
\text { danışmanlık } \\
\text { hizmeti } \\
\text { Öğretmen- } \\
\text { uygulama }\end{array}$ & $\begin{array}{l}\text { Kaynaştırma } \\
\text { sınıfı }\end{array}$ & $\begin{array}{l}\text { Araştırmada yer alan } \\
\text { öğrencilerin tümü kendilerine } \\
\text { özel eğitim danışmanlığı } \\
\text { aracılığıyla sağlanan resimli } \\
\text { fişleri okuma ve yazma } \\
\text { öğretiminde başarılı olmuştur. }\end{array}$ \\
\hline $\begin{array}{l}\text { Orçan ve } \\
\text { Özmen (2012) }\end{array}$ & Araştırmacı & $\begin{array}{l}\text { Öyküler } \\
\text { Performans } \\
\text { grafiği } \\
\text { Ödül listesi }\end{array}$ & $\begin{array}{l}\text { Hafif düzey } \\
\text { zihin } \\
\text { yetersizliği } \\
\text { olan } 2 \\
\text { öğrenci }\end{array}$ & $\begin{array}{l}\text { Öğrenci öyküyü } 3 \text { kez okur. } \\
\text { Öğrencinin bir dakikada okuduğu } \\
\text { sözcükler kaydedilir. } \\
\text { Öğrenci ödül seçer. } \\
\text { Bir dakikada doğru okuduğu } \\
\text { sözcük sayısında } \% 3-\% 5 \text { artış } \\
\text { hedeflenir. } \\
\text { Grafik üzerinde dönüt verilir. } \\
\text { Hedeflenen sayıda doğru sözcük } \\
\text { okuduğunda ödül verilir. }\end{array}$ & $\begin{array}{l}\text { Araştırmacı - } \\
\text { uygulayıcı } \\
\text { Öğrenci - } \\
\text { öğrenen }\end{array}$ & $\begin{array}{l}\text { Okul } \\
\text { kütüphanesi }\end{array}$ & $\begin{array}{l}\text { Birinci öğrencide okuma hızının } \\
\text { artmasında birleștirilmiş̧ } \\
\text { sağaltım paketlerinden Tekrarlı } \\
\text { okuma-performans dönütünün } \\
\text { etkili olduğu bulunmuştur. } \\
\text { İkinci öğrencide okuma hızının } \\
\text { artmasında tekrarlı okuma } \\
\text { sağaltım tekniği daha etkilidir. }\end{array}$ \\
\hline $\begin{array}{l}\text { Özak ve } \\
\text { Avcioğlu } \\
(2012)\end{array}$ & Araştırmacı & $\begin{array}{l}\text { PowerPoint } \\
\text { Eşzamanlı } \\
\text { ipucuyla öğretim } \\
\text { Kayıt formları }\end{array}$ & $\begin{array}{l}\text { Zihin } \\
\text { yetersizliği } \\
\text { olan } 6 \\
\text { öğrenci }\end{array}$ & $\begin{array}{l}\text { Öğrenciler bilgisayar ekranında } \\
\text { gözüken sözcükleri okumuş ve } \\
\text { sözcüğe ilişkin ses verilmiştir. } 4 \\
\text { saniye yanıt aralığı süresi } \\
\text { uygulanmıș, doğru tepkiler } \\
\text { pekiştirilmiş, yanlış cevaplar } \\
\text { görmezden gelinmiş, cevaplar } \\
\text { kaydedilmiștir. }\end{array}$ & $\begin{array}{l}\text { Araştırmacı - } \\
\text { uygulayıcı } \\
\text { Öğrenci - } \\
\text { öğrenen }\end{array}$ & $\begin{array}{l}\text { Eğitim } \\
\text { uygulama } \\
\text { okulu } \\
\text { bilgisayar sınıfi } \\
\text { Birebir ögretim }\end{array}$ & $\begin{array}{l}\text { Bilgisayar aracılı̆̆ıyla sunulan } \\
\text { eşzamanlı ipucuyla öğretim } \\
\text { öğrencilerin görsel sözcükleri } \\
\text { okumasını \%0 seviyesinden } \\
\% 80-100 \text { seviyesine çıkarmıştır. }\end{array}$ \\
\hline
\end{tabular}




\section{Kodlama Güvenirliği}

Bu çalışmada iki tür güvenirlik sağlanmıştır. Birinci tür güvenirlik anahtar kelimelerin ve derleme ölçütlerinin tespit edilmesinde sağlanmıștır. Araştırmacılar tarafından oluşturulan anahtar kelimeler ve derleme ölçütleri Türkiye'de özel eğitim ve okuma öğretimi alanlarında çalışmaları olan bir öğretim üyesi tarafından incelenmiştir. Bu uzman incelemesi sonucunda derlemede kullanılan anahtar kelimelere ve ölçütlere son şekli verilmiştir. Örneğin okuduğunu anlama, akıcı okuma ve okuma müdahalesi gibi anahtar kelimeler uzman görüșü sonucunda aramaya eklenmiştir.

İkinci tür güvenirlik tespit edilen çalışmaların kodlanması ile ilgili olmuştur. Çalışmaların kodlama ile ilgili güvenirliği özel eğitim ve Kültürel-Tarihsel Etkinlik Kuramı alanında çalışmaları olan ikinci bir kodlayıcı (öğretim üyesi) tarafından sağlanmıştır. On bir çalışma arasından rastgele seçilen üç çalışma (\%27) ikinci kodlayıcı tarafından bağımsız bir şekilde kodlanmıştır. Kodlayıcıların kodlamaları karşılaştırılmış ve güvenirlik yüzdesi \%100 olarak hesaplanmıștır. Güvenirlik yüzdesi hesaplanırken şu formül kullanılmıştır (Kazdin, 2011): (Uzlaşılan kod sayısı/Uzlaşılan kod sayısı + uzlaşılamayan kod sayısı) X 100.

\section{Bulgular}

\section{Özne}

İncelenen on bir çalışmanın dokuzunda (82\%) uygulamalar araştırmacılar tarafından yapılmıştır. Kırcaali-İftar ve Uysal (1999) uygulamaların öğretmenler tarafından ve Güzel-Özmen ve Vayiç (2007) ise uygulamaların ikinci yazar/araştırmacı aynı zamanda sınıf öğretmeni tarafından gerçekleștirildiğini belirtmiştir.

\section{Hedef}

On bir çalışmanın tamamında (100\%) hafif düzeyde zihin yetersizliği olan öğrenciler hedef öğrenci grubunu oluşturmuştur. Toplamda hafif düzeyde zihin yetersizliği bulunan 58 öğrenci çalışmalarda katılımcı olarak yer almıştır. Bu öğrencilerin 25'i kız 33'ü ise erkektir. Öğrencilerin yaș aralıkları beş yaș ile 14 yaș arasında değişmiştir.

\section{Yöntem ve Araç Gereçler}

Yöntem ve araç gereç kullanımı çalışmalar arasında farklılık göstermiştir. Akoğlu ve Turan (2012) çalışmasında ses bilgisel farkındalık becerileri eğitimi programı kullanmıştır. Atik-Çatak ve Tekinarslan (2008) Microsoft PowerPoint programında kelime görselleri hazırlamışlardır. Benzer şekilde Özak ve Avcıŏ̆lu (2012) Microsoft PowerPoint programından kelime okuma becerisini eş zamanlı ipucuyla öğretim yöntemiyle öğretmişlerdir. Demir ve Doğanay-Bilgi (2018) okul öncesi dönem için yazıca zenginleștirilmiş oyunlar geliştirip öğrencilerin okuma becerilerini okul öncesi dönemde sözcük ve yazı farkındalığı değerlendirme aracı ile ölçmüşlerdir. Duman ve ÇifciTekinarslan (2007) öğrencilerin okuma becerilerini geliştirmek için 15 hikaye belirleyerek, hikaye haritası yöntemi ve okuduğunu anlama ölçü aracı kullanmışlardır. Benzer şekilde Işıkdoğan ve Kargın da (2010) hikâye haritası yöntemi, şema ve izleme formu ve okuduğunu anlama formlarını kullanmıştır. Güldenoğlu ve Kargın (2012) tarafından karşılıklı öğretimle sunulan okuduğunu anlama öğretim programı kullanılmıştır. Kırcaali-İftar ve Uysal (1999) tarafından resimli fişlerle okuma öğretimi yöntemi kullanılmıștır. Orçan ve Özmen (2012) sınıf düzeyi öyküler, performans grafiği ve ödül listelerini kullanmıștır. Güzel-Özmen (2011) șematik düzenleyiciler kullanarak 
okuma öğretimi gerçekleştirmiştir. Son olarak, Güzel-Özmen ve Vayiç (2007) okuma becerilerini öğretmek için strateji öğretimi, kendini izleme tablosu, resimli kartlar ve fişler kullanmıştır.

\section{Kurallar}

Akoğlu ve Turan'ın (2012) çalışması ön test, uygulama ve son test aşamalarından oluşmuştur. Uygulamaya katılan çocuklara toplamda sekiz aşamadan ve ardışık on dört oturumdan oluşan ses bilgisel farkındalık becerileri okuma programı bireysel olarak uygulanmıştır. Program her öğrenci için kesintisiz olarak ve günde 45'er dakikalık bireysel eğitim oturumları şeklinde uygulanmıştır. Program aşamaları basitten karmaşığa kolaydan zora doğru sıralanmıştır. Bir aşama tamamlanmadan bir sonraki aşamaya geçilmemiştir. Her uygulama oturumundan sonra değerlendirme yapılmış ve bir sonraki aşamaya geçilip geçilmeyeceği ile ilgili karar verilmiştir.

Atik-Çatak ve Tekinarslan'ın (2008) çalışmasında başlama düzeyi ve uygulama verileri toplanmıștır. Başlama düzeyi oturumları öğrenciyle bire bir gerçekleştirilmiş ve 20 dakika ile sınırlandırılmıștır. Öğrencilerin kelime, cümle ve metin anlama becerileri kayıt formlarına işlenmiştir. Öğretim oturumlarında kelime ile ilgili dört oturum, cümle anlama ile ilgili dört oturum ve metin anlama ile ilgili beş oturum gerçekleştirilmiştir. Oturumlar 20 dakika ile sınırlandırılmıștır. Öğrencilerden PowerPoint sunusunda gördükleri kelimeleri okumaları istenmiştir. Ayrıca, öğrencilerden okuduğu kelimeyi anlatan görseli bulması istenmiş ve doğru cevaplar ödülle pekiştirilmiştir. Okuduğu cümleyi anlamada öğrencinin sunuda yer alan cümleleri okuması istenmiş ve hatalar düzeltilmiştir. Cümlede eylem ve kişiler üzerinde konuşulmuş ve öğrenciden cümle ile ilgili soruları cevaplaması istenmiştir. Okuduğu metni anlamada öğrencilerden slayttaki görselleri yorumlaması, metni sesli okuması, görselleri takip ederek metindeki olayı anlatması ve soruları cevaplaması beklenmiştir.

Demir ve Doğanay-Bilgi'nin (2018) çalışmasında uygulama her bir öğrenci için sekiz oturum sürmüş ve her bir oturumda yazıca zenginleștirilmiş bir oyun oynanmıştır. Oyun sıraları her bir öğrenci için aynı oluşturulmuştur. Yazı farkındalığı öğretim amaçları artan bir şekilde oyunların içine yerleştirilmiştir. Önceki bir oyunda öğrenilen yazı farkındalığı becerileri yeni oyunda yeni beceriler ile tekrar edilmiştir. Öğrencinin yazı farkındalığına yönelik doğru tepkileri pekiştirilmiș, yanlışlar ise yeniden öğretilmiștir.

Duman ve Çifci-Tekinarslan'ın (2007) çalıșması başlama düzeyi, öğretim oturumları ve izleme oturumlarından oluşmuştur Başlama düzeyinde üç hikâye ve bu hikayelere bağlı hazırlanmış okuduğunu anlama ölçü araçları kullanılmıştır. Öğrenciden hikayeleri sesli okumaları istenmiş, uygulamacı hikâyeye göre hazırlanmış soruları öğrenciye sırasıyla sormuş ve yanıtları kayıt çizelgesine işaretlemiştir. Öğretim oturumlarında öğrenciler her oturumda aynı öğelerden oluşan farklı hikayeler okumuşlardır. Uygulamacı, öğrencilerden okuma sırasında kendilerine verilen hikâye haritasını doldurulmalarını istemiş ve gerektiğinde model olmuştur. Öğrencilerden hikayeler ile ilgili sorulan sorulara \%80 doğru yanıt vermesi beklenmiştir. Oturumlar sınıf ortamında öğrenciyle bire bir gerçekleştirilmiştir.

Güldenoğlu ve Kargın'ın (2012) çalışması başlama düzeyi, yoklama oturumları, öğretim oturumları ve izleme oturumlarından oluşmuştur. Tüm oturumlar her gün iki oturum olacak şekilde bireysel olarak sınıfta gerçekleştirilmiştir. Oturumlarda sürekli pekiştirme tarifesi sözel olarak kullanılmıștır. Başlama düzeyinde öğretim yapılmadan öğrenciler hikayeleri okumuş ve araştırmacının sorduğu soruları cevaplamıştır. Öğretim oturumlarında karşılıklı öğretim yönteminin basamakları olan tahmin etme, soru sorma, açıklama ve özetleme becerileri öğretilmiştir. Öğrencilerin okudukları metin ile ilgili 
sorulan sorulara bağımsız doğru cevapları, yanlış cevapları ve tepkide bulunmama verileri toplanmış ve grafik olarak sunulmuştur.

Işıkdoğan ve Kargın'ın (2010) çalışmasında deney ve kontrol grubuna yerl eştirilecek öğrencilerin okuduğunu anlama becerileri öntest ile belirlenmiştir. Araştırmacılar tarafından seçilen hikâye öğrencilere okutulmuş ve hikâyeye ilişkin okuduğunu anlama soruları tüm çocuklara bireysel olarak uygulanmıștır. Uygulama aşamasında deney grubu öğrencilerine hikâye haritası tekniği kullanılarak 16 öğretim oturumu düzenlenmiştir. Her oturum günde 40 dakika ve haftada dört gün olacak şekilde planlanmıştır. Her bir öğrenciye seçilen hikâye okutularak sekiz bileșenli okuduğunu anlama soruları sorulmuştur. Öğretim oturumlarında her öğrenci ile hikâye haritası tekniği aşamaları (model olma, rehberlik, test, süreklilik) takip edilmiştir. Uygulama bittikten sonra tüm öğrencilerin okuduğunu anlama becerileri sontest ile belirlenmiştir.

Kırcaali-İftar ve Uysal'ın (1999) çalışmasında ilk okuma yazma öğretimi resimli fişler yaklaşımı ile öğretilmiştir. Resimli fişlerde sözcükleri temsil eden resimler yer almıştır. Öğrencilerin her sözcüğe karşı tek bir resim seçmesi istenmiştir. Fiş ilk kez tanıtılırken öğrenciden resmin neyi temsil ettiğini tahmin etmesine firsat verilmemiştir. Resimli fişler, öğretmenin benimsediği öğretim yöntemiyle öğretilmiștir. Resmi geciktirme ve resimsiz okuma uygulamaları yapılmıştır.

Orçan ve Özmen'in (2012) çalışmasında üç sağaltım paketinin etkililiği incelenmiştir: tekrarlı okuma-ödül, tekrarlı okuma-performans dönütü ve tekrarlı okuma-performans dönütü-ödül. Sağaltım tekniklerinde en kolay uygulanandan en zor uygulanana doğru bir sıralama izlenmiștir. Her öğrenci ile haftada beş gün ikişer oturum yapılmıștır. Tekrarlı okuma-ödül sağaltımında öğrenciye ödül listesinden bir ödül seçtirilmiş ve istenilen sayıda doğru sözcük okuduğunda bu ödülü alabileceği bildirilmiştir. Öğrenci öyküyü üç kez okumuş ve bir dakikada yanlış oku duğu kelimeler kaydedilmiş ve bir dakikada doğru okuduğu kelime sayısında \%3-\%5 artış hedeflenmiştir. Tekrarlı okuma-performans dönütünde öğrenci öyküyü üç kez okumuş, öğrenci performansı grafikleştirilmiş ve öğrenciye geri dönüt verilmiştir. Öğrencinin hedeflenen sözcük sayısına ulaşıp ulaşmadığı grafik üzerinden gösterilmiştir. Tekrarlı okuma-performans dönütü-ödül sağaltımında öğrenciye çalışma öncesinde ödül listesinden bir ödül seçtirilmiş ve öğrenci öyküyü üç kez okumuştur. Öğrencinin bir dakikada okuduğu sözcükler grafikleștirilmiş ve performans dönütü verilmiştir. Öğrenciye hedeflenen sayıda doğru sözcük okuduğunda ödül verilmiştir.

Özak ve Avcıoğlu'nun (2012) çalışmasında bilgisayar aracılığı ile sunulan eş zamanlı ipucuyla öğretimin etkililiği incelenmiştir. Araștırma pilot çalışma, başlama düzeyi, öğretim oturumları, izleme ve genelleme oturumlarından oluşmuştur. Sözcükler günlük yaşamda işlevsel olarak kullanılan ve üzerinde sadece yazı bulunan yer ve yön bildiren levhalardan oluşmuştur. Öğrencilerden bilgisayar ekranında gözüken sözcükleri okumaları, sözcüğe ilişkin ses vermeleri ve dört saniye yanıt aralığında yanıt vermeleri beklenmiştir. Uygulayıcı doğru tepkileri pekiştirmiş, yanlış cevapları görmezden gelmiş ve öğrenci cevaplarını kaydetmiştir.

Güzel-Özmen'in (2011) çalışması bilgi veren metinlerden karşılaştırma metinlerindeki benzerlik ve farklılıkları hatırlamada şematik düzenleyicilerin okuma öncesi ve okuma sonrası etkililiğini incelemiștir. Çalıșmada başlama düzeyi olarak metinler öğrencilere sessiz okutulmuş ve benzerlik ve farklılıklar üzerine sorular sorularak kararlılık sağlanmıştır. Karşılaştırma şeması ile ilgili öğrenciye okuma öncesi veya sonrası bilgi verilmiş ve şema doldurtulmuştur. Öğrencilere boş karşılaştırma şeması verilerek hatırladığı benzerlikleri söylemesi ve sonra kısa cümleler veya anahtar kelimeler kullanarak şema doldurtulmuştur. Öğrencilerle haftanın beş günü bire bir 
öğretim olacak şekilde çalışılmıştır. Cevaplar kayıt çizelgesine evet veya hayır şeklinde not edilmiştir. İki farklı sunum arasında yarım saat ara verilmiş ve uygulamanın sıra etkisini kontrol etmek için uygulama sırası tesadüfi örnekleme ile belirlenmiştir.

Güzel-Özmen ve Vayiç'in (2007) çalışmasında oku-altını çiz-böl birleștir stratejisinin öğrencilerin hece tanıma becerilerine etkililiği incelenmiştir. Çalışmanın başlama düzeyinde öğrenciler seçilen fişlerin hecelerini ve hecelerden oluşturulan kelimeleri okumuştur. Uygulama aşamasında strateji öğretiminin aşamaları olan tartışma, model olma (araştırmacı strateji basamaklarının nasıl uygulanacağını yüksek sesle düşünerek ve uygulayarak model olmuştur), rehberli uygulama (strateji kullanımında öğrenciye rehber olmuştur) ve geri dönüt verme sırasıyla takip edilmiștir. Model olma oturumları 26 ile 50 dakika, rehberli uygulama oturumları 14 ile 46 dakika, bağımsız uygulama oturumları 11 ile 40 dakika arasında sürmüştür. Deney süreci iki ayda tamamlanmıştır.

\section{İş Bölümü}

Araştırmalarda iş bölümünde yer alanlar şu şekilde belirtilmiştir: (a) araştırmacılar, (b) öğrenciler, (c) öğretmenler, (d) öğrencinin ailesi, (e) eğitim danışmanı ve (f) araştırma görevlileri. On bir çalışmanın dokuzunda (82\%) araştırmacılar-uygulayıcı ve tamamında (100\%) öğrenciler-öğrenen rolünde iş bölümüne katılmışlardır. İki çalışmada (\%18; Kırcaali-İftar ve Uysal, 1999; Güzel-Özmen ve Vayiç, 2007) öğretmenler uygulayıcı olarak görev almışlardır. Aile bireylerinin iş bölümüne dahil olduğu tek çalışmada öğrencinin annesinden uygulanan çalışmanın sosyal geçerliği ile ilgili veri toplanmıştır (Güldenoğlu ve Kargın, 2012). Demir ve Doğanay-Bilgi'nin (2018) çalışmasında özel eğitim öğretmeni ve Güzel-Özmen ve Vayiç'in (2007) çalışmasında araştırma görevlileri uygulama güvenirliğini kontrol etmek için iş bölümüne dahil olmuşlardır.

\section{Ortam}

Okuma müdahalelerinin uygulandığı ortamlar özel eğitim ve rehabilitasyon merkezleri (Akoğlu ve Turan, 2012; Güldenoğlu ve Kargın, 2012), özel eğitim sınıfları (Duman ve Çifci-Tekinarslan, 2007; Güzel-Özmen ve Vayiç, 2007) ve kaynaştırma sinıfları (AtikÇatak ve Tekinarslan, 2008; Kırcaali-İftar ve Uysal, 1999) olarak belirtilmiştir. Ayrıca okullardaki ayrı oda/sınıf (Demir ve Doğanay-Bilgi, 2018; Işıkdoğan ve Kargın, 2010; Güzel-Özmen, 2011), kütüphane (Orçan ve Özmen, 2012) ve eğitim uygulama okulunun bilgisayar sınıfı (Özak ve Avcıŏglu, 2012) okuma müdahalelerini uygulamak için kullanılmıştır.

\section{Sonuçlar}

Okuma müdahalelerine katılan öğrencilerin uygulamalar sonucunda okuma becerilerinde ilerleme olduğu raporlaştırılmıştır. Akoğlu ve Turan (2012) uygulamaya katılan öğrencilerin uyak farkındalığı, hece harf becerileri, sesbirim farkındalığı, harfleri isimlendirme becerileri, ses bilgisel farkındalık, metni toplam okuma süresi, okuma hataları, sözcükleri birbirinin yerine koyma ve okuma hatalarını düzeltme becerileri bakımından kontrol grubuna göre anlaml düzeyde olumlu performans sergilediğini bulmuştur. Atik-Çatak ve Tekinarslan (2008) uygulamadan sonra öğrencilerin kelime anlama düzeylerinde $\% 10-\% 20$, cümle anlama düzeylerinde $\% 30-\% 50$ ve metni anlama düzeylerinde \%40 artış olduğunu bulmuştur.

Demir ve Doğanay-Bilgi (2018) başlama düzeyine göre yazıca zenginleștirilmiş oyun ile yazı farkındalığı becerileri öğretimi sonunda öğrencilerin aldıkları puanlarda ortalama 19,05 puan artış olduğunu belirtmiştir. Bir diğer çalışmada ise Duman ve Çifci- 
Tekinarslan (2007) çalışmaya katılan üç öğrencinin de okuduğunu anlama sorularına verdikleri cevapların yüzdesini \%88-\%100 olarak raporlaştırmıştır.

Güldenoğlu ve Kargın (2012), okuma müdahalesi sonrasında üç öğrencinin de okuduğu metni özetleme ile ilgili becerilerin hepsine doğru tepki verdiğini bulmuştur. Işıkdoğan ve Kargın (2010) okuduğunu anlamada hikaye haritası tekniği kullanılarak yapılan öğretim oturumlarının, bu uygulamaya katılan öğrencilerin anlama düzeylerini arttırdığını bulmuştur. Kırcaali-İftar ve Uysal'ın (1999) araştırmasına katılan dört öğrencinin tamamı özel eğitim danışmanlığı aracılığı ile sağlanan resimli fişleri okuma ve yazma öğretimi çalışmalarında başarılı olmuştur. Hafif düzeyde zihin yetersizliği olan iki öğrenci ile yapılan çalışmada Orçan ve Özmen (2012) öğrencilerin okuma hızlarını artırmada birleştirilmiş sağaltım paketlerinden tekrarlı okuma-performans dönütünün ve tekrarlı okuma sağaltım paketinin etkili olduğunu belirtmiştir.

Özak ve Avcıoğlu (2012) bilgisayar aracılı̆̆ı ile sunulan eşzamanlı ipucuyla öğretimin öğrencilerin görsel sözcükleri okumasını \%0 seviyesinden \%80-\%100 seviyesine çıkardığını bulmuştur. Güzel-Özmen (2011) metinde bulunan farklılık ve benzerlikleri hatırlamada şematik düzenleyiciyi okuma sonrası doldurmanın, okuma öncesi şematik düzenleyicinin sunumuna göre daha etkili olduğunu bulmuştur. Son olarak, Güzel-Özmen ve Vayiç (2007) tarafından yapılan çalışmanın sonucunda üç öğrencinin de fiş hecelerini $\% 100$, kelimeleri \%88-\%100 ve cümle içindeki kelimeleri \%88-\%100 oranında doğru okuduğu bulunmuştur.

\section{Tartışma}

$\mathrm{Bu}$ çalışmada zihin yetersizliği olan öğrenciler için uygulanan okuma müdahalelerinin Kültürel-Tarihsel Etkinlik Kuramı bağlamında bir analizi sunulmuştur. Yapılan analizlerin zihin yetersizliği olan öğrencilere okuma öğretiminde üzerinde durulması gereken kültürel ve tarihsel faktörleri tartışmaya yönelik bir başlangıç olması amaçlanmıştır. Analizlerden elde edilen veriler okuma müdahalelerinin araştırmacı temelli olduğunu, kullanılan araç-gereç ve yöntemler arasında farklılıklar bulunmasına rağmen öğrencilerin okuma performanslarında ilerleme gözlendiğini, öğrenci ve ailelerinin süreçte pasif hedef rolünde yer aldıklarını ve müdahale ortamlarının kapsayıcı olmaktan uzak olduğunu göstermektedir.

$\mathrm{Bu}$ derleme sonuçlarına göre Kültürel-Tarihsel Etkinlik Kuramı bileșenlerinden biri olan ortam üzerinde bir tartışma yapılması gerekliliği gözlenmektedir. İncelenen çalışmalar temelinde zihin yetersizliği olan öğrencilerin genel eğitim müfredatına ve ortamına erişim konusunda literatürde bir eksiklik olduğu görülmektedir. Tarihsel süreç incelendiğinde zihin yetersizliği olan öğrencilerin eğitimleri ve genel eğitim müfredatına erişimleri konusunda beklentiler artmaktadır. Genel eğitim müfredatına erişim, zihin yetersizliği olan öğrencilerin anlamlı ve sınıf düzeyine uygun okuma becerileri öğrenmelerini destekleyecek içerik geliştirmeye yönelik daha esnek düşünmeyi gerektirmektedir. Bu araştırmanın uygulama ortamlarına ilişkin sonuçları eğitimcilerin anlamlı ve sınıf düzeyine uygun okuma programı geliştirme ve bunları kaynaştırma sınıflarında uygulama konusunda yol göstermesine yönelik bir ihtiyaç olduğunu göstermektedir. İncelenen araştırmalarda uygulama ortamlarının çoğunlukla normal akranlardan ayrı ortamlar olduğu bulunmuştur. Son yıllarda araştırmacılar zihin yetersizliği olan öğrenciler için okuma öğretiminin ayrı ortamlardan ziyade kaynaştırma sınıflarında yapılmasına yönelik tavsiyelerde bulunmaktadır (Copeland ve Keefe, 2019; Toews ve Kurth, 2019). Özellikle, araştırmacılar ayrı ortamlarda ya da özel eğitim sınıflarında etkili ve kanıt temelli olduğu raporlaştırılan uygulamaların genel eğitim ortamlarında nasıl kullanılabileceği ile ilgili uygulamalar gerçekleştirmelidir. 
Analizler ayrıca Kültürel-Tarihsel Etkinlik Kuramı bileşenlerinden bir diğeri olan yöntem veya araç gereçler bağlamında zihin yetersizliği olan öğrenciler için yaygın ve etkili okuma müdahalelerine yönelik daha fazla çalışma yapılması gerektiğini göstermektedir. Okuma müdahaleleri, fiş kelimeleri öğretimi, resim-kelime eşleme, bilgisayardan kelime okuma, oyun aracılığı ile öğretim gibi çeşitli uygulamalar ve araç gereçleri içermektedir. Özellikle, hikâye haritası veya șemaları okuma etkinliklerinde yaygın bir yöntem olarak kullanılabilir (Duman ve Çifci-Tekinarslan, 2007; Güzel-Özmen, 2011; Işıkdoğan ve Kargın, 2010). İlaveten, genel literatüre bakıldığında çok bileşenli okuma müdahalelerinin hem genel eğitim öğrencileri (Edmonds vd., 2009; Foorman ve Torgesen, 2001) hem de zihin yetersizliği olan öğrencilerin okuma becerileri üzerinde etkili olduğu bulunmuştur (Afacan vd., 2018; Allor vd., 2014; Browder vd., 2012). Geçmiş çalışmalar temelinde Türkiye'de zihin yetersizliği olan öğrenciler için çok bileşenli okuma programlarının (ses bilgisel farkındalık, ses-sembol eşleme, kelime bilgisi, akıcı okuma ve okuduğunu anlamayı içeren) geliştirilmesine ve uygulamalarının yapılmasına ihtiyaç duyulmaktadır.

Araştırma sonuçları Kültürel-Tarihsel Etkinlik Kuramının bir diğer bileşeni olan iş bölümü açısından incelendiğinde ise çalışmalarda planlama, uygulama ve değerlendirme aşamalarında karar vericilerin çoğunlukla araştırmacıların olduğu görülmektedir. Bu sonuç kullanılan araştırma yöntemleri ile ilgili olsa da zihin yetersizliği olan öğrencilere anlamlı ve sınıf düzeyine uygun okuma müdahaleleri uygulamak için öğrencilerin ve ailelerinin ilgi ve beklentilerinin de okuma müdahalesi geliștirme ve uygulama süreçlerine dahil edilmesi gerekmektedir (Copeland ve Keefe, 2019). Uygulama ortamı ve okuma metinlerinin seçimi konusunda uygulayıcıların diğer paydaşlar ile (özellikle öğrenciler ve aileler) birlikte planlama yapmasının önemi ortaya çıkmaktadır. Okuma metinlerinin öğrencinin ilgi ve tercihlerine göre seçilmesi öğrencinin motivasyonunu dolayısıyla okuma başarısını artırabilecek bir faktördür (Edmunds ve Bauserman, 2006). Müdahaleler planlanırken araştırmacıların diğer paydaşlarla (aile, öğrenci, diğer öğretmenler) birlikte çalışması önemlidir. İncelenen çalışmalarda öğrencilerin okuma becerilerinde gelişimler görülmekle birlikte bu çalışmaların okuma müdahalelerini planlama ve uygulama aşamalarında farklı paydaşlarla birlikte nasıl bir çalışma yapılabileceği konusunda yeterli bilgi sunamadıkları görülmektedir.

Kültürel-Tarihsel Etkinlik Kuramı temelinde biçimlendirici müdahaleler okuma müdahalelerinin geliştirilmesi sürecinde kullanılabilecek analitik bir araç olarak kullanılabilir. Biçimlendirici müdahalelerde araştırmacılar diğer paydaşlarla birlikte araştırma sürecinde katılımcı olarak bir durumu/işleyişi araştırma ve geliştirmeyi amaçlar (Engeström, 2016). Bunu gerçekleştirmek için bir değişim döngüsünü takip ederler (Şekil 3). Değişim döngüsü; (1) mevcut problem durumu sorgulama, (2) problem durum ile ilgili analizler yapma, (3) probleme karşı yeni bir uygulama ya da model oluşturma, (4) yeni modeli inceleme, (5) uygulama için plan yapma, (6) süreci ve ürünü değerlendirme ve (7) gerçek uygulama aşamalarını içermektedir (Engeström, 2000; 2016). Bu değişim döngüsü zihin yetersizliği olan öğrenciler için okuma müdahaleleri geliştirilirken kullanılabilecek analitik bir araç olarak kullanılabilir. Öğrencilerin, ailelerin, araștırmacıların ve diğer paydaşların aktif katılımıyla etkili ve anlamlı okuma müdahaleleri geliştirilebilir.

Bu makalede biçimlendirici müdahaleler hakkında derinlemesine bir bilgi sağlamak amaçlanmamıştır. Biçimlendirici müdahaleler ABD'den Finlandiya'ya, Güney Afrika'dan Brezilya'ya kadar geniş bir alanda uygulanmaktadır. Bu müdahalelerin çeşitli birimlerde başarıyla kullanıldığı bulunmuştur. Örneğin; Engeström (2000) Helsinki'deki bir çocuk hastanesindeki sistemsel problemleri çözmek için biçimlendirici müdahaleyi 
kullanmıştır. Bir başka çalışmada Engeström vd. (2013) Helsinki'deki bir üniversite kütüphanesinin sistemini öğrenci ve araştırmacıların yeni ihtiyaçlarına göre yeniden düzenlemek için yerel paydaşlarla birlikte biçimlendirici müdahale gerçekleştirmiştir. ABD'de yapılan bir çalışmada Bal vd. (2018), aileler, eğitimciler, sivil toplum kuruluşları ve araştırmacılar ile birlikte bir devlet lisesinde olumlu, bütünleştirici, çevreye uyumlu ve etkili yeni okul-çaplı bir disiplin sistemini geliştirmişlerdir. Farklı ülkelerde yapılan uygulamalarla biçimlendirici müdahalelerin etkililiği ve sürdürülebilirliği tespit edilmiştir (Engeström, 2016; Virkkunen ve Newnham, 2013). Biçimlendirici müdahaleler mevcut uygulamaları daha da ilerletmek ve aile, tüm paydaşları uygulamalara dahil etmek ve ekolojik sistem-çapll, kaynaştırmaya yönelik müdahale modelleri geliștirmek amacıyla zihin yetersizliği olan öğrencilere okuma müdahaleleri geliştirmek amacıyla kullanılabilir.

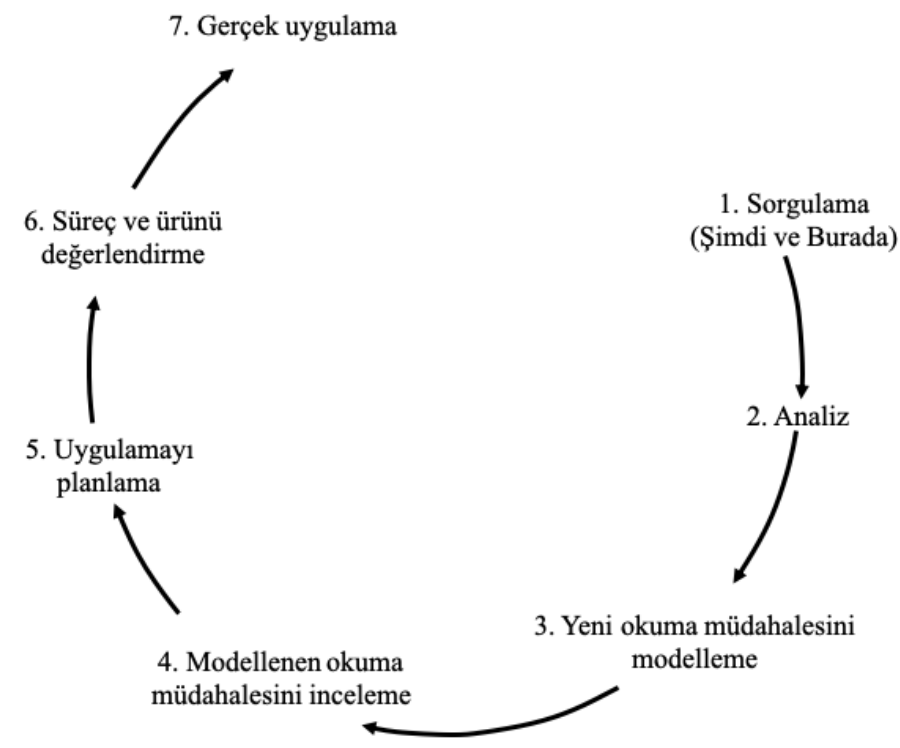

Şekil 3. Değişim döngüsü (Engeström, 1987; Bal vd., 2018'den uyarlanmıştır)

\section{Sinırlılıklar ve Öneriler}

Bu çalışmada TR dizin veri tabanında (ULAKBİM) yer alan çalışmalar ve dergi arşivleri incelenmiștir. TR dizin statüsünde olmayan dergiler derlemeye dahil edilmemiștir. $\mathrm{Bu}$ yüzden, TR dizin olmayan dergiler ve bu dergilerde yayınlanmış olabilecek makalelerin incelemeye dahil edilmemesi bir sınırlılık olarak kabul edilebilir. Bir diğer sınırlılık ise ulaşılan araştırmaların dahil edilme ölçütleri doğrultusunda belirlenen arama motorunun sonuçlarıyla sınırlı olmasıdır. Ayrıca konu ile ilgili yazılmış tezlerin incelenmesi de derlemeye dahil edilebilecek çalışma sayısında bir artışa neden olabilecektir.

$\mathrm{Bu}$ derlemenin amacı zihin yetersizliği olan öğrenciler için uygulanan okuma müdahalelerini Kültürel-Tarihsel Etkinlik Kuramı temelinde incelemektir. Tespit edilen çalışmaların incelenmesi sonucunda gelecek çalışmalara yol gösterebilecek iki önemli soru ortaya çıkmıştır. Birincisi, farklı paydaşlarla birlikte zihin yetersizliği olan öğrenciler için etkili bir okuma müdahalesi nasıl geliştirilebilir? Bu noktada gelecek çalışmalarda okuma müdahaleleri geliştirmek için farklı paydaşların birlikte iş birliği içinde çalıştıkları biçimlendirici müdahalelerin uygulanması tavsiye edilmektedir.

İkinci önemli soru, zihin yetersizliği olan öğrencilere genel eğitim sınıflarında okuma öğretimi yaparken kullanılabilecek kanıt temelli yöntemler nelerdir? Çalışmaların büyük 
çoğunluğu ayrı sınıflarda bire bir ortamlarda gerçekleștirilmiştir. Kaynaştırma ortamında gerçekleştiği belirtilen çalışmalar ise okuma öğretiminin bu ortamlarda nasıl uygulandığına yönelik bilgi vermede yetersiz kalmıştır. Bunun için gelecek çalışmalar farklı paydaşların genel eğitim müfredatı içeriğini uyarlama, araç gereç ve materyal geliştirme ve kanıt temelli yöntemleri belirleme konusunda iş birliği içinde nasıl çalışabileceğini araştırmalıdır.

\section{Kaynakça}

Afacan, K., Wilkerson, K. L., \& Ruppar, A. L. (2018). Multicomponent reading intervention for students with intellectual disability. Remedial and Special Education, 39(4), 229-242. https://doi.org/10.1177/0741932517702444

Akçin, N. (2006). Engelli çocukları konuşmaya cesaretlendirmek için hikâye okuma. Marmara Üniversitesi Atatürk Eğitim Fakültesi Eğitim Bilimleri Dergisi, 23, 1-17.

Akçin, F. N. (2019). Zihinsel yetersizliği olan çocuklar için hibrit okuma-yazma öğretim yöntemi. Ankara Üniversitesi Eğitim Bilimleri Fakültesi Özel Eğitim Dergisi,20(1), 177-208. https://doi.org/10.21565/ozelegitimdergisi.413092

*Akoğlu, G., \& Turan, F. (2012). Eğitsel müdahale yaklaşımı olarak sesbilgisel farkındalık: Zihinsel engelli çocuklarda okuma becerilerine etkileri. Hacettepe Üniversitesi Ĕ̆itim Fakültesi Dergisi, 42, 11-22.

Allor, J. H., Mathes, P. G., Roberts, J. K., Cheatham, J. P., \& Al Otaiba, S. (2014). Is scientifically based reading instruction effective for students with below-average IQs? Exceptional Children, 80(3), 287-306. https://doi.org/10.1177/0014402914522208

American Association on Intellectual and Developmental Disabilities. (2021, January 6). Definition of intellectual disability. https://www.aaidd.org/intellectualdisability/definition

*Atik-Çatak, A., \& Tekinarslan, E. (2008). Powerpoint programında hazırlanan okuma materyalinin 12-13 yaşlarında kaynaştırma programına devam eden hafif düzeyde zihinsel engelli öğrencilerin okuduğunu anlama becerisine etkisi. Abant İzzet Baysal Üniversitesi Eğitim Fakültesi Dergisi, 8(2), 107-124.

Bal, A. (2018). Culturally responsive positive behavioral interventions and supports: A process oriented framework for systemic transformation. Review of Education, Pedagogy, and Cultural Studies, 40(2), 144-174.

https://doi.org/10.1080/10714413.2017.1417579

Bal, A., Afacan, K., \& Cakir, H. I. (2018). Culturally responsive school discipline: Implementing learning lab at a high school for systemic transformation. American Educational Research Journal, 55(5), 1007-1050. https://doi.org/10.3102/0002831218768796

Başal, M., \& Batu, E. S. (2002). Zihin özürlü öğrencilere okuma yazma öğretme konusunda alt özel sınıf öğretmenlerinin görüş ve önerileri. Ankara Üniversitesi Eğitim Bilimleri Fakültesi Özel Eğitim Dergisi, 3(2), 85-98. https://doi.org/10.1501/Ozlegt 0000000067

Browder, D. M., Ahlgrim-Delzell, L., Flowers, C., \& Baker, J. (2012). An evaluation of a multicomponent early literacy program for students with severe developmental disabilities. Remedial and Special Education, 33(4), 237-246. 
https://doi.org/10.1177/0741932510387305

Browder, D. M., \& Xin, Y. P. (1998). A meta-analysis and review of sight word research and itsimplications for teaching functional reading to individuals with moderate and severe disabilities. The Journal of Special Education,32(3), 130-153. https://doi.org/10.1177/002246699803200301

Brown, L., Hermanson, J., Klemme, H., Haubrich, P., \& Ora, J. P. (1970). Using behavior modification principles to teach sight vocabulary. Teaching Exceptional Children, 2, 120-128. https://doi.org/10.1177/004005997000200303

Brown, L., Huppler, B., Pierce, L., York, B., \& Sontag, E. (1974). Teaching trainable-level students to read unconjugated action verbs. The Journal of Special Education, 8(1), 51-56. https://doi.org/10.1177/002246697400800110

Brown, L., Jones, S., Troccolo, E., Heiser, C., Bellamy, T., \& Sontag, E. (1972). Teaching functional reading to young trainable students: Toward longitudinal objectives. Journal of Special Education, 6(3), 237-246.

https://doi.org/10.1177/002246697200600306

Cole, M (1996). Cultural psychology. Harvard University.

Compton-Lilly, C. (2012). Reading time: The literate lives of urban secondary students and their families. Teachers College Press.

Copeland, S. R., \& Keefe, E. B. (2007). Effective literacy instruction for students with moderate or severe disabilities. Brookes Publishing Co.

Copeland, S. R., \& Keefe, E. B. (2019). Literacy instruction for all students within general education settings. Research and Practice for Persons with Severe Disabilities, 44(3), 143-146. https://doi.org/10.1177/1540796919866011

Çetrez-İşcan, G. \& Coşkun, İ. (2016). Okuma stratejilerinin hafif derecedeki zihinsel yetersizliği olan bir öğrencinin akıcı okumasına ve anlama düzeyine etkisi. Turkish Studies, 11(3), 821-846. http://dx.doi.org/10.7827/TurkishStudies.9296

*Demir, M., \& Doğanay-Bilgi, A.(2018). Yazıca zenginleştirilmiş oyunun anaokuluna devam eden zihin yetersizliği olan öğrencilerin yazı farkındalığı becerilerine etkisi. Elementary Education Online, 17(1), 450-468.

*Duman, N., \& Çifci-Tekinarslan, İ. (2007). Hikâye haritası yönteminin hafif düzeyde zihinsel, yetersizliği olan öğrencilerin okuduğunu anlama becerileri üzerindeki etkisi. Ankara Üniversitesi Eğitim Bilimleri Fakültesi Özel Eğitim Dergisi, 8(1), 3359. https://doi.org/10.1501/Ozlegt 0000000104

Edmonds, M. S., Vaughn, S., Wexler, J., Reutebuch, C., Cable, A., Tackett, K. K., \& Schnakenberg, J. W. (2009). A synthesis of reading interventions and effects on reading comprehension outcomes for older struggling readers. Review of Educational Research, 79(1), 262-300. https://doi.org/10.3102/0034654308325998

Edmunds, K. M., \& Bauserman, K. L. (2006). What teachers can learn about reading motivation through conversations with children. The Reading Teacher, 59(5), 414424.

Engeström, Y. (1987). Learning by expanding. Orienta-Konsultit. 
Engeström, Y. (2000). Activity theory as a framework for analyzing and redesigning work. Ergonomics, 43(7), 960-974. https://doi.org/10.1080/001401300409143

Engeström, Y. (2008). From teams to knots. Cambridge University.

Engeström, Y. (2016). Studies in expansive learning: Learning what is not yet there. Cambridge University Press.

Engeström, Y., Rantavuori, J., \& Kerosuo, H. (2013). Expansive learning in a library: Actions, cycles and deviations from instructional intentions. Vocations and Learning, 6(1), 81-106.

Foorman, B. R., \& Torgesen, J. (2001). Critical elements of classroom and small group instruction promote reading success in all children. Learning Disabilities Research \& Practice, 16(4), 203-212. https://doi.org/10.1111/0938-8982.00020

Gargiulo, R. M., \& Bouck, E. C. (2018). Etiology of intellectual disability and characteristics of students with intellectual disability. In R. M. Gargiulo, \& E. C. Bouck (Eds.), Instructional strategies for students with mild, moderate, and severe intellectual disability (pp. 29-48). Sage Publications Inc.

Gutiérrez, K., \& Penuel, W. (2014). Relevance to practice as a criterion for rigor. Educational Researcher, 43, 19-23. https://doi.org/10.3102/0013189X13520289

Güldenoğlu, B. (2008). Zihinsel yetersizliği olan öğrencilerde okuduğunu anlama becerilerinin desteklenmesi. Ankara Üniversitesi Ĕgitim Bilimleri Fakültesi Özel Eğitim Dergisi, 9(2), 51-63.

*Güldenoğlu, B., \& Kargın, T. (2012). Karşılıklı öğretim tekniğinin hafif derecede zihinsel engelli öğrencilerin okuduğunu anlama becerileri üzerindeki etkililiğinin incelenmesi. Ankara Üniversitesi Eğitim Bilimleri Fakültesi Özel Eğitim Dergisi, 13(1), 17-34. https://doi.org/10.1501/Ozlegt 0000000164

*Güzel-Özmen, R. (2011). Zihinsel yetersizliği olan öğrencilerin bilgi veren metinlerdeki bilgiler hatırlamalarında şematik düzenleyicilerin iki farklı sunum şeklinin karşılaştırılması. Kuram ve Uygulamada Eğitim Bilimleri, 11(2), 785-793.

*Güzel-Özmen, R., \& Vayiç, Ş. (2007). Oku-altını çiz-böl-birleştir stratejisinin zihinsel engelli öğrencilerin hece tanıma becerilerini kazanmalarında etkililiği. Ankara Üniversitesi Eğitim Bilimleri Fakültesi Özel Eğitim Dergisi,8(2), 1-18. https://doi.org/10.1501/Ozlegt 0000000116

Individuals With Disabilities Education Improvement Act of 2004, 20 U,S,C, $\S 1400$ et seq.(2004), Reauthorization of the Individuals With Disabilities Education Act of 1990.

*Işıkdoğan, N., \& Kargın, T. (2010). Hikâye haritası tekniğinin zihin engelli öğrencilerin okuduğunu anlama becerilerini kazanmalarındaki etkililiği. Kuram ve Uygulamada Eğitim Bilimleri, 10(3), 1489-1531.

Hassett, D. D. (2008). Teacher flexibility and judgment: A multidynamic literacy theory. Journal of Early Childhood Literacy, 8(3), 295-327. https://doi.org/10.1177/1468798408096479 
Katims, D. S. (2000). Literacy instruction for people with mental retardation: Historical highlights and contemporary analysis. Education and Training in Mental Retardation and Developmental Disabilities, 35(1), 3-15.

Kazdin, A. E. (2011). Single-case research designs: Methods for clinical and applied settings (2nd ed.). Oxford University Press.

*Kırcaali-İftar, G., \& Uysal, A. (1999). Zihin özürlü öğrencilere özel eğitim danıșmanlığı aracılığıyla uygulanan resimli fişlerle okuma-yazma öğretiminin etkililiği. Ankara Üniversitesi Eğitim Bilimleri Fakültesi Özel Eğitim Dergisi,2(3), 3-13. https://doi.org/10.1501/Ozlegt_0000000046

Kurtdere-Fidan, N., \& Akyol, H. (2011). Hafif düzeyde zihinsel öğrenme güçlügü olan bir öğrencini okuma ve anlama becerilerini geliştirmeye yönelik nitel bir çalışma. Kuramsal Eğitimbilim Dergisi, 4(2), 16-29.

Mirenda, P. (2003). "He's not really a reader": perspectives on supporting literacy development in individuals with autism. Topics in Language Disorders, 23(4), 271282.

No Child Left Behind Act (2001). U.S. Department of Education.

*Orçan, M., \& Özmen, E. R. (2012). Zihinsel yetersizlikten etkilenmiş öğrencilerin okuma hızının artırılmasında sağaltım paketlerinden etkili olanın belirlenmesi. Ankara Üniversitesi Eğitim Bilimleri Fakültesi Özel Eğitim Dergisi,13(1), 41-54. https://doi.org/10.1501/Ozlegt 0000000165

*Özak, H., \& Avcıoğlu, H. (2012). Zihinsel yetersizliği olan öğrencilere okuma becerilerinin öğretiminde bilgisayar aracılığıyla sunulan eş zamanlı ipucuyla öğretimin etkililiği. Abant İzzet Baysal Üniversitesi Eğitim Fakültesi Dergisi, 12, 33-50.

Penuel, W. R. (2014). Emerging forms of formative intervention research in education. Mind, Culture, and Activity, 21, 97-117. https://doi.org/10.1080/10749039.2014.884137

Sannino, A., Daniels, H., \& Gutierrez, K. (2009). Learning and expanding with activity theory. Cambridge University.

Schulte, A. C., Stevens, J. J., Elliott, S. N., Tindal, G., \& Nese, J. F. (2016). Achievement gaps for students with disabilities: Stable, widening, or narrowing on a state-wide reading comprehension test? Journal of Educational Psychology, 108(7), 925-942. https://doi.org/10.1037/edu0000107

Sucuoğlu, B. (Ed.). (2017). Zihin engelliler ve eğitimleri (3rd. ed.). Ankara: Kök Yayıncılık. Şengül, H., \& Akçin, N. (2010). Zihinsel yetersizliği olan öğrencilere okuma yazma öğretme konusunda özel eğitim öğretmenlerinin görüşleri. Ankara Üniversitesi Eğitim Bilimleri Fakültesi Dergisi, 43(2), 1-26.

Toews, S. G., \& Kurth, J. A. (2019). Literacy instruction in general education settings: A call to action. Research and Practice for Persons with Severe Disabilities, 44(3), 135-142. https://doi.org/10.1177/1540796919855373

Waitoller, F. R., \& Kozleski, E. B. (2013). Understanding and dismantling barriers for partnerships for inclusive education: A cultural historical activity theory perspective. International Journal of Whole Schooling, 9(1), 23-42. 
Wei, X., Blackorby, J., \& Schiller, E. (2011). Growth in reading achievement of students with disabilities, ages 7 to 17. Exceptional Children, 78(1), 89-106. https://doi.org/10.1177/001440291107800106

Virkkunen, J. \& Newnham, D. S. (2013). The change laboratory: A tool for collaborative development of work and education. Sense.

Vygotsky, L. S. (1978). Mind in society. Harvard University.

Yamagata-Lynch, L. C., \& Haudenschild, M. T. (2009). Using activity systems analysis to identify inner contradictions in teacher professional development. Teaching and Teacher Education, 25(3), 507-517. https://doi.org/10.1016/j.tate.2008.09.014

\section{Extended Summary}

\section{Reading Interventions for Students with Intellectual Disability: A Cultural-Historical Review}

\section{Introduction}

Reading that is one of the academic skill areas is known as the area where students with intellectual disabilities (ID) have the lowest achievement. Past studies have shown that students with ID have lower reading skills compared to other students. It would not be right to associate students' low reading performance with their learning process and capacity only. It is also necessary to determine by whom, using which methods and materials, in which environment, with whom support, and with which rules, reading interventions are implemented for students with ID. Reading is not only an individual activity but also has a cultural and historical form. The purpose of this review was to present a cultural-historical analysis of reading interventions implemented for students with ID. We provided a brief history of reading instruction implemented for students with ID and cultural-historical activity theory (CHAT) was mentioned in order to bring a theoretical perspective to the reviewed studies.

Especially in the last decade, CHAT has attracted considerable interest in various fields such as education, organizational psychology, medical education, public health, computer and industrial engineering, and agriculture in countries such as the United States, Finland, Australia, Taiwan, and Brazil. CHAT may be useful for researchers, teachers, psychologists, and other stakeholders who are working in the field of special education in Turkey. The purpose of this study was to provide a cultural-historical framework for reading interventions implemented for students with ID. It was aimed to find out the factors that affect the process of teaching reading to students with ID.

\section{Method}

\section{Article Selection Process}

Articles were identified through TR Index (ULAKBIM) database and electronic archives of 24 education-related journals in Turkey. TR Index that was developed by TUBITAK is a database of scientific journals in Turkey aiming to reach international standards. We used the following keywords: (Level 1) okuma öğretimi OR okuma müdahalesi OR reading instruction OR reading intervention (Level 2) okuduğunu anlama OR reading comprehension OR akıcı okuma OR fluency OR kelime OR vocabulary (Level 3) zihin engelli 
OR zihinsel yetersizlik OR zihin yetersizliği OR zihinsel engelli OR intellectual disability OR cognitive disability OR mental retardation. We also conducted hand searches of 24 journals that were indexed in TR Index.

\section{Inclusion Criteria}

Four criteria were established for the articles to be included in the study. The first criterion was determined as the description of reading intervention. In order to meet the first criteria, researchers had to state that they used quantitative or single-subject research methods in their studies. As a second criterion, it was determined that reading intervention should be implemented for a student with ID. The third criterion was that studies needed to be published in a TR Index (ULAKBIM) journal. The last criterion was that studies had to be written in Turkish or English. Articles that did not meet these criteria were not examined. A total of 11 studies met the inclusion criteria in this review.

\section{Coding}

Seven coding categories within the context of CHAT were used for the eleven identified studies. These coding categories were subject, artifacts, object, division of labor, rules, community, and outcome. The subject is who has been involved in implementing the reading intervention (e.g., teacher, family, researcher); artifacts, methods and various tools used in reading intervention (e.g., direct instruction, story mapping, strategy instruction); object, who the reading intervention targeted (e.g., whole class instruction, small group instruction, individual instruction); division of labor, the distribution of responsibilities among those involved in intervention (e.g., collaborative teaching, implementation fidelity); rules, under which rules the intervention was implemented (e.g., duration, ratio, reinforcement); community, in which environment the intervention took place (e.g., separate classroom, resource room, general education classroom); and outcome refers to what kinds of results were obtained after the reading intervention (e.g., reading fluency, reading comprehension, vocabulary).

\section{Results}

According to the results of this study, students with mild ID were participants in all reviewed studies. Results showed that students with ID did not have access to reading instruction in general education classrooms. Studies were mostly conducted in separate or self-contained special education classrooms rather than general education classrooms. Results also showed a lack of effective and grade level reading interventions for students with ID. Interventions included various strategies such as teaching sight words, pictureword matching, reading words from the computer, and game-based teaching. Moreover, researchers were identified as interventionists in the majority of the studies (\%82). Results from this study did not provide sufficient information regarding how to work with different stakeholders in planning and to implement reading interventions for students with ID. Students and their families were involved as passive objects in the process, and intervention environments did not support inclusive practices.

\section{Discussion}

We presented a review of reading interventions implemented for students with ID in the context of CHAT. The analyses are intended to initiate a discussion about cultural and historical factors that should be considered in teaching reading to students with ID. 
Results showed that reading interventions were researcher-based, there were variations among tools and methods used across the studies, students and families were situated as passive objects in the studies, and intervention environments were not inclusive. The results of this study regarding the implementation environments show that there is a need for developing and implementing effective reading programs (including a different combination of phonemic awareness, phonics, vocabulary, fluency, and comprehension) in Turkey and implementing these interventions in inclusive settings. Students and their families' interests and expectations should be included in the intervention process to implement meaningful and grade-level reading interventions for students with ID. In this article, we suggested that formative interventions could be used as an analytical tool to improve existing practices and to develop ecologically valid and inclusive reading interventions for students with ID. In formative interventions, researchers follow a cycle of change process including the following stages: (1) questioning, (2) analyzing, (3) modeling, (4) examining, (5) implementing, (6) reflecting on the process, and (7) actual implementation. This cycle of change can help researchers, students, families, and other stakeholders to actively collaborate in designing effective and meaningful reading interventions for students with ID.

\section{Yazar(lar)ın Beyanı}

Araştırmacıların katkı oranı beyanı: Araştırmacılar çalışmaya eşit oranda katkı yapmışlardır.

Etik Kurul Kararı: Bu makalede sunulan çalışmanın bir derleme çalışması olması nedeniyle etik kurul iznine gerek duyulmamaktadır.

Çatışma beyanı: Araştırmada yazarlar arasında ya da diğer kişi/kurum/kuruluşlarla herhangi bir çıkar çatışması bulunmamaktadır.

Destek ve teşekkür: $\mathrm{Bu}$ araştırma için herhangi bir kurumdan finansal destek alınmamıştır. 